\title{
Poly(4-Hydroxybutyrate): Current State and Perspectives
}

\author{
Camila Utsunomia', Qun Ren² and Manfred Zinn ${ }^{1 *}$ \\ 1 Institute of Life Technologies, University of Applied Sciences and Arts Western Switzerland (HES-SO Valais-Wallis), Sion, \\ Switzerland, ${ }^{2}$ Laboratory for Biointerfaces, Empa, Swiss Federal Laboratories for Materials Science and Technology, \\ St. Gallen, Switzerland
}

\section{OPEN ACCESS}

Edited by:

Yuya Tachibana,

Gunma University, Japan

Reviewed by:

Takeharu Tsuge,

Tokyo Institute of Technology, Japan

Christopher Nomura,

SUNY College of Environmental

Science and Forestry, United States

*Correspondence:

Manfred Zinn

manfred.zinn@hevs.ch

Specialty section:

This article was submitted to Biomaterials,

a section of the journal

Frontiers in Bioengineering and

Biotechnology

Received: 10 January 2020

Accepted: 12 March 2020

Published: 03 April 2020

Citation:

Utsunomia $C$, Ren $Q$ and Zinn $M$ (2020) Poly(4-Hydroxybutyrate): Current State and Perspectives.

Front. Bioeng. Biotechnol. 8:257.

doi: 10.3389/fbioe.2020.00257
By the end of 1980s, for the first time polyhydroxyalkanoate (PHA) copolymers with incorporated 4-hydroxybutyrate $(4 \mathrm{HB})$ units were produced in the bacterium Cupriavidus necator (formally Ralstonia eutropha) from structurally related carbon sources. After that, production of PHA copolymers composed of 3-hydroxybutyrate $(3 \mathrm{HB})$ and $4 \mathrm{HB}[\mathrm{P}(3 \mathrm{HB}-\mathrm{co}-4 \mathrm{HB})]$ was demonstrated in diverse wild-type bacteria. The P4HB homopolymer, however, was hardly synthesized because existing bacterial metabolism on $4 \mathrm{HB}$ precursors also generate and incorporate $3 \mathrm{HB}$. The resulting material assumes the properties of thermoplastics and elastomers depending on the $4 \mathrm{HB}$ fraction in the copolyester. Given the fact that $\mathrm{P} 4 \mathrm{HB}$ is biodegradable and yield $4 \mathrm{HB}$, which is a normal compound in the human body and proven to be biocompatible, $\mathrm{P} 4 \mathrm{HB}$ has become a prospective material for medical applications, which is the only FDA approved PHA for medical applications since 2007. Different from other materials used in similar applications, high molecular weight P4HB cannot be produced via chemical synthesis. Thus, aiming at the commercial production of this type of PHA, genetic engineering was extensively applied resulting in various production strains, with the ability to convert unrelated carbon sources (e.g., sugars) to $4 \mathrm{HB}$, and capable of producing homopolymeric P4HB. In 2001, Metabolix Inc. filed a patent concerning genetically modified and stable organisms, e.g., Escherichia coli, producing P4HB and copolymers from inexpensive carbon sources. The patent is currently hold by Tepha Inc., the only worldwide producer of commercial P4HB. To date, numerous patents on various applications of $\mathrm{P} 4 \mathrm{HB}$ in the medical field have been filed. This review will comprehensively cover the historical evolution and the most recent publications on P4HB biosynthesis, material properties, and industrial and medical applications. Finally, perspectives for the research and commercialization of $\mathrm{P} 4 \mathrm{HB}$ will be presented.

Keywords: biopolymer, biopolyester, biobased, 4-hydroxybutyric acid, medicine, implants, tissue engineering, drug delivery

\section{INTRODUCTION}

In 1926, the first polyhydroxalkanoate (PHA), poly(3-hydroxybutyrate) (P3HB) (Figure 1), was discovered by the French scientist Maurice Lemoigne during his work with the bacterium Bacillus megaterium (Lemoigne, 1926). In the late 1950s, the first industrial application was considered by W. R. Grace and followed by many other companies (Lenz and Marchessault, 2005). During 
the past 50 years, much research and development projects have been dedicated to the ever growing class of PHAs. To date, the number of known PHA monomers has increased to more than 140, including unsaturated and aromatic monomers (Kim et al., 2007; Hanik et al., 2019). Nevertheless, there is only limited production of PHA worldwide (Table 1) despite the increase of potential applications (Albuquerque and Malafaia, 2018). The reasons are quite diverse. The high production cost of which approximately 50\% are attributed to the precursor substrates, commonly pure sugars and fatty acids, limits the bulk application of PHAs (Koller et al., 2017). These microbial polyesters are estimated to be 3-4 times more expensive than synthetic plastics, such as polypropylene and polyethylene, and exhibit more inconsistent material properties (Kourmentza et al., 2017; Zhang et al., 2018). In addition, the availability of PHAs for process development is limited and, in many cases, the processing methods have to be fine-tuned to a specific polymer type (selection of appropriate additives, temperature profile adapted to optimal crystallization rate, etc.) (Bugnicourt et al., 2014). Last, but not least, stringent patent politics have limited further research and the interest of investors into product development. A window of application where PHAs can outcompete other materials is expected to be the medical field (Zinn et al., 2001; Valappil et al., 2006).

New insights in medicine revealed the big potential of resorbable biomaterials in tissue regeneration (Hench and Polak, 2002). A typical representative of this new generation biomaterial is the biopolymer polylactide (PLA) (Figure 1) which has been approved by the United States Food Drug and Administration (FDA) for various medical applications (Tyler et al., 2016). Despite its wide use, PLA has a few shortcomings, e.g., degradation by burst-release and liberating large amounts of lactic acid, which consequently leads to $\mathrm{pH}$ acidification of the environment. PHAs, on the other hand, are degraded by enzymatic interaction or by surface erosion via chemical hydrolysis (Martin and Williams, 2003). Out of the PHA family, poly(4-hydroxybutyric acid) (P4HB) (Figure 1) has properties especially suitable for medical applications (Table 2). The extremely high elasticity of $\mathrm{P} 4 \mathrm{HB}$ comparable to ultrahigh molecular weight polyethylene is one of its most interesting features (Martin and Williams, 2003). After 10 years of clinical trials, $\mathrm{P} 4 \mathrm{HB}$ is unique among all types of PHA produced to date, since it is the only PHA-based material with FDA clearances for clinical usage starting with an approval for monofilament suture applicable in general soft tissue approximation and/or ligation (Williams et al., 2013; Zhang et al., 2018). Since our society, more than ever, has been searching for alternatives to synthetic plastics, the bio-based, biodegradable, and biocompatible P4HB stands out as a material with both high market value as well as large market potential.

\section{GENERAL ASPECTS OF PHA AND P4HB}

Polyhydroxyalkanoate is a family of polyesters synthesized by various microorganisms under limitation of a nutrient, besides carbon, essential to cell growth (e.g., nitrogen, phosphorous), and accumulated intracellularly as a stock of energy in the form of PHA granules [also known as carbonosomes (Jendrossek, 2009)]. PHAs are typically divided into three subgroups where the criteria is the number of carbons on the side chain of the repeating monomer unit: short-chain-length PHA (scl-PHA) containing monomers up to five carbon atoms (C5), mediumchain-length PHA ( $m c l$-PHA) with C6-C14 monomers, and over C15 monomers the polymers are called long-chain-length PHAs (lcl-PHA) (Lu et al., 2009). The change of the monomeric unit composition is dictated by the bacterial producer, the type of PHA synthase $(\mathrm{PhaC})$ catalyzing the polymerization, and the substrate fed to the cells, providing PHA with various physical properties (Zinn and Hany, 2005). Once extracted from the cells, PHA can exhibit thermoplastic and elastomeric properties, i.e., scl-PHAs have properties resembling polyethylene or polypropylene while the $\mathrm{mcl}$-PHAs are comparable to elastomers and rubbers (Sudesh et al., 2000; Koller et al., 2010). Thus, the wide range of physical and material properties of PHAs coming from the variety of monomers makes them suitable as materials for different needs, including value-added medical and pharmaceutical applications (Wu et al., 2009). PHAs are hydrophobic, enantiomerically pure due to the stereo-specificity of PhaC toward $(R)$-3-hydroxyacids (3-HAs), biocompatible, and can be synthesized to molecular weights as high as several millions of $\mathrm{g} \mathrm{mol}^{-1}$ with low polydispersity (Steinbüchel and Lütke-Eversloh, 2003).

Biodegradation is the decomposition of organic materials/compounds by microorganisms or through biochemical reactions via enzymatic or non-enzymatic hydrolysis both aerobically or anaerobically. In contrast to petroleum-derived plastics, PHAs are considered as intrinsically biodegradable and the chiral center of the PHA monomer in $R$ configuration is key for the recognition and hydrolysis of the polymer by enzymes designated PHA depolymerases (PhaZ) (Amstutz et al., 2019). PhaZs are found intracellularly, located on the surface of PHA granules together with other enzymes associated to PHA synthesis, but also extracellularly, including a signal peptide to its protein structure. In addition, lipases, which are thought to present similar hydrolysis mechanism to PhaZs, can also degrade PHAs, particularly the ones without side chains (Ong et al., 2017). Therefore, PHA degradation takes place in environments with high microbial activity (e.g., soil, compost, and marine water) by growing on the polymer surface and secreting enzymes resulting in water-soluble oligomers and HAs which are taken up by the microorganisms. Ultimately, the products of PHA degradation are $\mathrm{CO}_{2}$ and $\mathrm{H}_{2} \mathrm{O}$, and $\mathrm{CO}_{2}$ and methane when it occurs aerobically and anaerobically, respectively. Environmental conditions, such as temperature and $\mathrm{pH}$, and $\mathrm{PHA}$ properties, likewise monomer type, molecular weight, crystallinity, and surface area, directly influence the degradation rate. In the environment, PHAs are observed to have a relatively fast degradation mostly via enzymatic attack (Jendrossek, 2001). Once in the human body, on the other hand, the degradation of PHAs (e.g., $\mathrm{P} 3 \mathrm{HB}$ and $\mathrm{P} 4 \mathrm{HB}$ ) is mediated by both non-enzymatic and enzymatic hydrolysis into products naturally found as metabolites in animals, favoring their use in medical applications (Deeken and Matthews, 2013; Ong et al., 2017). The hydrolysis of $\mathrm{P} 4 \mathrm{HB}$ in vivo has been reported 
TABLE 1 | Key players in the commercialization of PHAs today.

\begin{tabular}{|c|c|c|c|c|}
\hline Company & Raw material & PHA & Capacity & References \\
\hline Kaneka (Japan) & Plant oil & $\mathrm{P}(3 \mathrm{HB}-\mathrm{CO}-\mathrm{HHx})\left(\mathrm{PHBH}^{\mathrm{TM}}\right)$ & $\begin{array}{l}\text { Estimated production capacity of } \\
12 \text { '000 kilotons in } 2020\end{array}$ & 1 \\
\hline Tepha Inc. (United States) & Not reported & $\begin{array}{l}\left.\text { P4HB (TephaFLEX }{ }^{\circledR}\right) \text { and } \\
\text { copolymers } \\
\left.\text { (TephaELAST }{ }^{\oplus}\right)\end{array}$ & Not reported & 2 \\
\hline $\begin{array}{l}\text { Danimer Scientific } \\
\text { (United States) }\end{array}$ & Canola oil & mcl-PHA (Nodax $\left.{ }^{T M}\right)$ & $\begin{array}{l}\text { Commercial plant (estimated to } \\
\text { operate at } 10 \text { '000 tons per year) }\end{array}$ & 3 \\
\hline $\begin{array}{l}\text { Tianjin Green Biosciences Co., } \\
\text { Ltd., (China) }\end{array}$ & Not reported & P(3HB-co-4HB) (GreenBio) & 10 '000 tons per year & Greene, 2014; ${ }^{4}$ \\
\hline PHB Industrial S/A (Brazil) & Sugar from sugarcane & $\mathrm{P} 3 \mathrm{HB}\left(\mathrm{BioCycle}^{\circledR}\right)$ & 50 tons per year & 5 \\
\hline Bio-on (Italy) & $\begin{array}{l}\text { Molasses and by-products of sugar beet } \\
\text { production }\end{array}$ & P3HB (Minerv-PHA ${ }^{T M}$ ) & Demonstration plant & \\
\hline Mango Materials (United States) & $\begin{array}{l}\text { Raw biogas (methane, carbon dioxide, and } \\
\text { hydrogen sulfide) }\end{array}$ & $\mathrm{P} 3 \mathrm{HB}$ & $\begin{array}{l}\text { Pilot facility ( } 250 \text { kg per year). } \\
\text { Short-term goal: } 100 \text { kg per week }\end{array}$ & \\
\hline
\end{tabular}

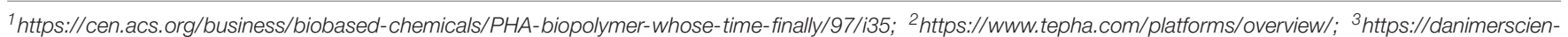

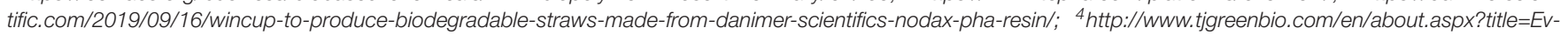
ents\&cid=26; ${ }^{5}$ http://www. canaverde.com.br/produtos/.

to be initiated by the diffusion of water molecules into the polymer matrix cleaving the chains of P4HB (Williams et al., 2016). Polymer surface erosion is driven by enzymes, possibly non-specific lipases and esterases (Brigham and Sinskey, 2012; Williams et al., 2016). PHASIX mesh and P4HB plug, materials made of $\mathrm{P} 4 \mathrm{HB}$ for soft tissue repair, are degraded and fully resorbed within 12-18 months (Deeken and Matthews, 2013). The majority of PHAs are composed of 3-HAs, but also 4-, 5-, 6-HAs are polymerized in PHAs. The hydrolytic attack of such PHA ester bonds is less prone to take place in comparison to polymers composed by 2-HAs, such as polyglycolic acid (PGA) and PLA (Figure 1), thus, in general, the hydrolysis rate of PHAs is comparatively slower (Koyama and Doi, 1995).

In 2018, the global production of plastics reached nearly 360 million tonnes (PlasticsEurope, 2019). Around $40 \%$ is destined to packaging and half of it is used in food packaging (Albuquerque and Malafaia, 2018). However, the fraction coming from bioplastics (biobased and biodegradable) is almost negligible. In 2016, 0.9 million tons of biodegradable plastics, comprising PHAs, PLA, and starch blends, were produced worldwide and it is expected to increase to 1.3 million tons by 2021 (Albuquerque and Malafaia, 2018). Even though PHAs are

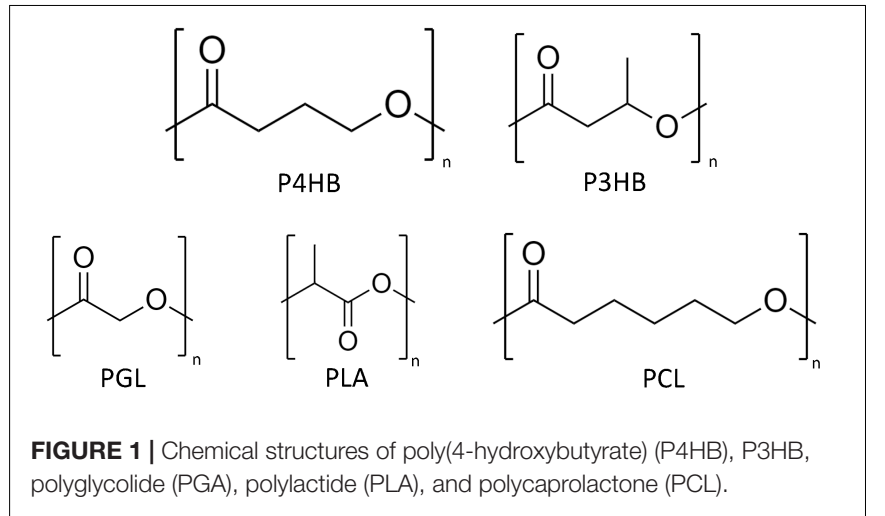

suitable materials to traditional polymer processing techniques resulting in daily life products (e.g., packaging, garbage bags, bottles) (Bugnicourt et al., 2014), due to its high cost and interesting material properties, PHAs find relevancy in medical applications. Medical devices, matrices for tissue repair and organ reconstruction, and particles for drug delivery, have been developed using PHAs (Williams et al., 1999; Wu et al., 2009). $\mathrm{P} 4 \mathrm{HB}$, in particular, stands out among both PHAs and polymers conventionally used for medical applications as a material that has the strength of conventional suturing materials but is much more flexible. Undergoing traditional processing techniques (e.g., solvent casting, melting extrusion) and innovative methods, the biocompatible $\mathrm{P} 4 \mathrm{HB}$ has been used in the preparation of new and improved biomaterials (e.g., implants, materials for tissue engineering and wound care) filling up the gaps existing when slow in vivo degradation is required, for example (Martin and Williams, 2003; Williams et al., 2013). However, limited commercial availability of $\mathrm{P} 4 \mathrm{HB}$ might be one of the reasons hindering the exploitation of its huge potential in medical applications.

TABLE 2 | Comparison of properties of P4HB with other thermoplastic polyesters [adapted from Martin and Williams (2003)].

\begin{tabular}{lccccc}
\hline Polymer & $\mathbf{T m}\left({ }^{\circ} \mathbf{C}\right)$ & $\mathbf{T g}\left({ }^{\circ} \mathbf{C}\right)$ & $\begin{array}{c}\text { Tensile } \\
\text { strength } \\
\text { (MPa) }\end{array}$ & $\begin{array}{c}\text { Tensile } \\
\text { modulus } \\
\text { (MPa) }\end{array}$ & $\begin{array}{c}\text { Elongation at } \\
\text { break (\%) }\end{array}$ \\
\hline P4HB & 60 & -51 & 50 & 70 & $1^{\prime} 000$ \\
PGA & 225 & 35 & 70 & $6^{\prime} 900$ & $<3$ \\
PLLA & 175 & 65 & $28-50$ & $1^{\prime} 200-2^{\prime} 700$ & 6 \\
PDLLA & $*$ & $50-53$ & $29-35$ & $1^{\prime} 900-2^{\prime} 400$ & 6 \\
PCL & 57 & -62 & 16 & 400 & 80 \\
P3HB & 180 & 1 & 36 & $2^{\prime} 500$ & 3 \\
\hline
\end{tabular}

Depending on the polymer, films were prepared by solvent casting and/or compression molding (Engelberg and Kohn, 1991). *, Amorphous; PDLLA, copolymer of D- and L-lactic acid; PCL, polycaprolactone. 


\section{P4HB PRODUCTION}

Commercial P4HB, unlike other resorbable polyesters (e.g., PLA, PGA, PCL), is exclusively synthesized in fermentation process. The chemical synthesis of $\mathrm{P} 4 \mathrm{HB}$ has been attempted, but failed to synthesize high molecular weight polymer necessary for most applications (Hori et al., 1995). Furthermore, the use of metal catalysts in the chemical synthesis results in polymers containing toxic metals that are not desired when medical applications are envisioned for such materials.

\section{Chemical Synthesis of P4HB}

One of the chemical synthesis approaches involves the ring-opening polymerization of monomer $\gamma$-butyrolactone. Unsuccessful and successful studies were attempted using various catalysts or initiators such as organometallic catalysts (Inoue et al., 1961), zwitterionic titanoxanes (Burlakov et al., 2003), clay catalyst (Miura et al., 1999), metal complex catalyst, and others (Moore et al., 2005). These resulted in oligomers with low degree of polymerization (DP 2 - 3) and polymers with number-average molecular weight $\left(M_{n}\right)$ of $\sim 5 \times 10^{3} \mathrm{~g} \mathrm{~mol}^{-1}$ (Moore et al., 2005), which do not have the same toughness and flexibility as high molecular weight $\mathrm{P} 4 \mathrm{HB}$ produced in vivo (over $10^{6} \mathrm{~g} \mathrm{~mol}^{-1}$ ) (Martin and Williams, 2003). Synthesis of higher molecular weight $\mathrm{P} 4 \mathrm{HB}$ with up to $5 \times 10^{4}$ and $M_{n}$ up to $3 \times 10^{4} \mathrm{~g} \mathrm{~mol}^{-1}$ was reported by Oishi et al. (2000) and Hong and Chen (2016), respectively. Oishi et al. (2000) have used Lewis acid catalysts at very high pressure, while Hong and Chen employed as catalyst a homoleptic compound, $\mathrm{La}\left[\mathrm{N}\left(\mathrm{SiMe}_{3}\right)_{2}\right]_{3}$, reacted with an alcohol initiator and $\gamma$-butyrolactone under ambient pressure. Alternatively, researchers have also developed chemo-enzymatic methods to prepare PHAs. For example, Nobes et al. (1996) disclosed the ring opening polymerization of $\gamma$-butyrolactone by mammalian and microbial lipases in $n$-hexane to yield P4HB with $M_{w}$ up to $932 \mathrm{~g} \mathrm{~mol}^{-1}$. Another synthetic strategy for $\mathrm{P} 4 \mathrm{HB}$ is the free radical ring-opening polymerization of 2-methylene dioxolane, resulting in a copolymer containing ring opened and unopened units (Bailey et al., 1982). 4HB has been successfully co-polymerized with $3 \mathrm{HB}$ via ring-opening polymerization of $\gamma$-butyrolactone and $\beta$-butyrolactone using a distannoxane complex as catalyst (Hori et al., 1995). The result, however, was copolymers with low weight-average molecular weight $\left(M_{w}\right)$ (less than $1 \times 10^{5} \mathrm{~g} \mathrm{~mol}^{-1}$ ), reaching the lowest values when less than $35 \mathrm{~mol} \% 4 \mathrm{HB}$ were polymerized (less than $8 \times 10^{3} \mathrm{~g} \mathrm{~mol}^{-1}$ ). Studies on the ring-opening polymerization for $\mathrm{P} 4 \mathrm{HB}$ synthesis were comprehensively reviewed (Moore et al., 2005). Alternatively, as described in the United States Pat. No. 5,563,239, condensation polymerization of esters employing titanium as catalyst under high temperatures was also attempted to synthesize PHAs in vitro (Hubbs and Harrison, 1996). More recently, Zhang et al. reported the synthesis of functional $\mathrm{P} 4 \mathrm{HB}$ (Zhang et al., 2013). By means of the Passerini multicomponent polymerization of $(E)$-4-oxobut-2-enoic acid with isocyanides followed by hydrogenation, functional $\mathrm{P} 4 \mathrm{HB}$ with a $M_{n}$ up to 8 ' $800 \mathrm{~g} \mathrm{~mol}^{-1}$ were synthesized. By varying the isocyanide compound, two different groups could be incorporated into the side chains of the polymers.
In a polycondensation reaction of 4-hydroxybutyric acids, the formation of lactone is kinetically favored in detriment of the ester bond formation, hampering the synthesis of high molecular weight $\mathrm{P} 4 \mathrm{HB}$ (greater than $1 \times 10^{5} \mathrm{~g} \mathrm{~mol}^{-1}$ ) in vitro (Niaounakis, 2015). Moreover, $\gamma$-butyrolactone has been commonly referred to in the literature as "non-polymerizable." Such statement was made due to the very small ring strain energy of the cyclic monomer. Due to this, under normal conditions, the extremely stable ester bond in the lactone ring is less prone to break and join onto the polymer chain than the ester in the growing polymer chain is probable to transesterify or undergo ring formation. Nevertheless, even the material resulted from high-pressure ring-opening polymerization reactions of $\gamma$-butyrolactone presented a molecular weight not higher than $5 \times 10^{4} \mathrm{~g} \mathrm{~mol}^{-1}$ (Moore et al., 2005).

\section{Biological Synthesis}

By varying the bacterium and its PHA polymerase (PhaC) together with the substrate $\mathrm{C}$ source, polymers with different monomeric composition and tailor-made mechanical properties are obtained. In addition, PHA producers, either wild-type or recombinant, are capable to synthesize PHAs with molecular weights higher than $10^{6} \mathrm{~g} \mathrm{~mol}^{-1}$. By changing the activity and concentration of active PhaC the molecular weight of PHAs can also be fine-tuned (Hiroe et al., 2012). Many of the catalysts used for the chemical synthesis of polyesters contain toxic metals (e.g., organic tin compounds) and these are completely avoided when using a biological process to produce PHAs.

\section{Production of PHA Copolymers Containing 4HB in Wild-Type Strains}

Polyhydroxyalkanoates containing $4 \mathrm{HB}$ as constituents were first discovered by Prof. Doi's research group in the late 1980's when Cupriavidus necator (formerly Ralstonia eutropha) was cultivated using 4-hydroxybutyric acid and $\gamma$-butyrolactone as $\mathrm{C}$ sources (Kunioka et al., 1988; Doi et al., 1990). Afterward, biosynthesis of such PHAs was achieved in Alcaligenes latus, Comamonas acidovorans, Hydrogenophaga pseudoflava (Choi et al., 1995), Burkholderia sacchari (Cesário et al., 2014; Mendonça et al., 2014), and others (Azira et al., 2011), which are known PHA producers having $\mathrm{PhaCs}$ polymerizing preferentially $\mathrm{scl}$ PHAs. PHA copolymers containing $3 \mathrm{HB}$ and $4 \mathrm{HB}[\mathrm{P}(3 \mathrm{HB}-$ co-4HB)] could only be synthesized in wild-type strains from structurally related carbon sources, such as 4-hydroxybutyric acid, $\gamma$-butyrolactone, 4-chlorobutyric acid (Doi et al., 1988), 1,4butanediol (BDO), and other $\omega$-alkanediols (Saito et al., 1996). $\mathrm{P} 4 \mathrm{HB}$ homopolymer, on the other hand, was hardly produced. Saito et al. (1996) observed the production of $\mathrm{P}(3 \mathrm{HB}-\mathrm{co}$ $4 \mathrm{HB}$ ) in C. necator from $4 \mathrm{HB}$ precursors (e.g., $\gamma$-butyrolactone, 1,4-butanediol) as unique carbon sources in nitrogen (N)free medium. When $\left(\mathrm{NH}_{4}\right)_{2} \mathrm{SO}_{4}$ and citrate were fed as a substrate mixture together with 4-hydroxybutyric acid, $\mathrm{P} 4 \mathrm{HB}$ homopolymer was produced along with a decrease in polymer content from $16 \mathrm{wt} \%$ of $\mathrm{P}(3 \mathrm{HB}-\mathrm{co}-13 \mathrm{~mol} \% 4 \mathrm{HB})$ to $2 \mathrm{wt} \%$ of $\mathrm{P} 4 \mathrm{HB}$. The metabolism of $4 \mathrm{HB}-\mathrm{CoA}$ directed to acetyl$\mathrm{CoA}$ rather than $3 \mathrm{HB}-\mathrm{CoA}$ under growth conditions was a possible reason for the production of $\mathrm{P} 4 \mathrm{HB}$ homopolymer. In 
the same study, C. acidovorans JCM10181 (formerly DS-17) was shown to produce $\mathrm{P} 4 \mathrm{HB}$ homopolymer with an accumulation of up to $28 \mathrm{wt} \%$ from 4-hydroxybutyric acid and 1,4-BDO as sole $\mathrm{C}$ sources in $\mathrm{N}$-free medium after $48 \mathrm{~h}$ of cultivation. Alcaligenes latus, which has a growth-related PHA production (Kourmentza et al., 2017), produced $\mathrm{P}(3 \mathrm{HB}-\mathrm{co}-45 \mathrm{~mol} \% 4 \mathrm{HB}$ ) from sucrose and $\gamma$-butyrolactone. In another publication (Kang et al., 1995), a copolymer with higher 4HB fraction (from 13 up to $83 \mathrm{~mol} \% 4 \mathrm{HB}$ ) was synthesized in A. latus from 4hydroxybutyric acid and 3-hydroxybutyric acid in a medium containing $\left(\mathrm{NH}_{4}\right)_{2} \mathrm{SO}_{4}$. Cell growth, however, decreased along with the increase of 4-hydroxybutyric acid concentration in the medium and the higher $4 \mathrm{HB}$ content in the polymer. Comamonas acidovorans and $A$. latus are not able to grow on $4 \mathrm{HB}$ precursors indicating a restricted metabolism of $4 \mathrm{HB}-\mathrm{CoA}$ to acetyl-CoA. This could explain the production of PHA with a high $4 \mathrm{HB}$ fraction in C. acidovorans. Although C. necator is also not able to grow neither on 4-hydroxybutyric acid nor 1,4-BDO, this strain produces copolymers from these $\mathrm{C}$ sources. The metabolism of $4 \mathrm{HB}$ in C. necator was studied by Valentin et al. (1995). A spontaneous mutant of C. necator HF39, denominated SK4040, could be isolated and showed growth on 4-hydroxybutyric acid. After Tn5::mob mutagenesis on SK4040 two classes of secondary mutants were generated, one not able to grow on 4hydroxybutyric acid $\left(4 \mathrm{HB}^{-}\right)$and a second with poorer growth on 4-hydroxybutyric acid compared to SK4040. A genomic fragment isolated from SK4040 differed from the one of $4 \mathrm{HB}^{-}$mutants. Cloning of such fragment in $C$. necator $\mathrm{H} 16$ conferred the wild-type the ability to grow on 4-hydroxybutyric acid. DNA sequence analysis indicated a structural gene encoding a 4hydroxybutyric acid dehydrogenase and enzymatic assays the existence of an active succinate-semialdehyde dehydrogenase. Thus, $4 \mathrm{HB}$ degradation was thought to take place via succinate semialdehyde and succinate followed by degradation through the citric acid cycle. In addition, no evidence for direct conversion of $4 \mathrm{HB}$ to $3 \mathrm{HB}$ was observed.

A close investigation on the PHA synthase $\left(\mathrm{PhaC}_{\mathrm{Ca}}\right)$ of C. acidovorans JCM10181 (Sudesh et al., 1998), suggested that the bacterial metabolism rather than a preference of $\mathrm{PhaC}_{\mathrm{Ca}}$ for $4 \mathrm{HB}$ $\mathrm{CoA}$ as substrate is the reason for efficient incorporation of $4 \mathrm{HB}$ into PHA. The efficient incorporation of $4 \mathrm{HB}$ by $C$. acidovorans JCM10181 was shown to depend on the $4 \mathrm{HB}$ precursor supplied (i.e., 4-hydroxybutyric acid, 1,4-BDO, and $\gamma$-butyrolactone), among which feeding 4-hydroxybutyric acid resulted in polymer with the highest $4 \mathrm{HB}$ fraction (96 mol\%) and accumulation up to $25 \%$ of the dry cell weight (Lee et al., 2004). Furthermore, reduced culture aeration and higher inoculum concentration to the $\mathrm{N}$-free medium containing the $4 \mathrm{HB}$ precursor were found to increase the $4 \mathrm{HB}$ fraction in the polymer. An increment in the $4 \mathrm{HB}$ fraction $(12.3$ to $51.8 \mathrm{~mol} \%)$ in the polymer produced by C. necator was obtained when small amounts of propionate along with $\gamma$-butyrolactone were added in the medium (Lee et al., 2000). PhaC activity was highly induced by the addition of propionate as well as the concentration of acetyl-CoA. The overflowing acetylCoA was proposed to inhibit the ketolysis reaction and thus reducing the lysis of $4 \mathrm{HB}-\mathrm{CoA}$ to two molecules of acetyl-CoA, consequently leading to an increase of the $4 \mathrm{HB}$ fraction available for polymerization. Corroborating with this presumption, the same effect in the $4 \mathrm{HB}$ fraction was observed when acetate was supplemented (Kim et al., 2005). The effect of dissolved oxygen tension (DOT) (2 and 20\%) and addition of propionic acid (2 g $\mathrm{L}^{-1}$ ) in PHA accumulation and $4 \mathrm{HB}$ fraction of a copolymer produced in C. necator DSM 545 was investigated in a high cell density fed-batch cultivation (Cavalheiro et al., 2012). Waste glycerol was used as $\mathrm{C}$ source for growth (and 3HB generation) and $\gamma$-butyrolactone as precursor of $4 \mathrm{HB}$. Higher DOT (20\%) favored PHA accumulation and was not significantly increased by the presence of propionic acid. The $4 \mathrm{HB}$ fraction, on the other hand, was largely increased by the addition of propionic acid as a $4 \mathrm{HB}$ stimulator and by prolonging the cultivation time. However, feeding propionic acid inherently resulted in a terpolymer composed by $3 \mathrm{HB}, 4 \mathrm{HB}$, and 3 -hxdroxyvalerate $(3 \mathrm{HV})$. The highest $4 \mathrm{HB}$ fraction of $30.6 \mathrm{~mol} \%$ in a terpolymer containing $6.7 \mathrm{~mol} \% 3 \mathrm{HV}$ was achieved with the addition of propionic acid and a DOT of $2 \%$. By optimizing the cultivation conditions, a polymer containing only $4 \mathrm{HB}$ was produced in $H$. pseudoflava (Choi et al., 1999). It consisted of a three-step cultivation as follows: $1^{\text {st }}$ stage) biomass formation on LB medium with undesired $\mathrm{P} 3 \mathrm{HB}$ accumulation (10 wt $\%), 2^{\text {nd }}$ stage) degradation of residual $\mathrm{P} 3 \mathrm{HB}$ in a $\mathrm{C}$-free medium containing ammonium sulfate, and $3^{\text {rd }}$ stage) synthesis of P4HB homopolymer (19.6 wt $\%, 0.474 \mathrm{~g} \mathrm{~L}^{-1}$ ) in a nitrogen-free medium containing $\gamma$-butyrolactone for $36 \mathrm{~h}$. It was observed that the activity of 4-hydroxybutyric acid dehydrogenase increased progressively over time in the presence of $\gamma$-butyrolactone. In a one-step cultivation at least $120 \mathrm{~h}$ were needed for the accumulation of $1.3 \mathrm{wt} \%$ of $\mathrm{P}(3 \mathrm{HB}-\mathrm{co}-63 \mathrm{~mol} \% 4 \mathrm{HB})$ from $\gamma$-butyrolactone. The activity of 4-hydroxybutyric acid dehydrogenase was 0.089 and $0.557 \mathrm{U} \mathrm{mg}^{-1}$ at $96 \mathrm{~h}$ and $144 \mathrm{~h}$ of one-step cultivation, respectively. The absence of $3 \mathrm{HB}$ incorporation into polymer in the three-step cultivation was assigned to the low activity of 4hydroxybutyric acid dehydrogenase during the short period of PHA accumulation ( $36 \mathrm{~h}$ ) leading to low levels of acetyl-CoA.

\section{Recombinant Strains for the Synthesis of P4HB Homopolymer and Copolymers From Structurally Related C Sources}

P3HB-leaky mutants of C. necator JMP222, defective in genes presumably involved in the regulation of $\mathrm{P} 3 \mathrm{HB}$ mobilization in the cells (Pries et al., 1991), were found by Steinbüchel et al. (1994) to accumulate low amounts of P4HB homopolymer (up $11.3 \mathrm{wt} \%$ ) from 4-hydroxybutyric acid. The introduction of a plasmid expressing the PHA biosynthetic genes of C. necator into the same mutant increased the cellular $\mathrm{P} 4 \mathrm{HB}$ content up to $27.2 \mathrm{wt} \%$. Due to the phaC extra copies, recombinant C. necator showed approximately five times higher activity than the PHA polymerase (synthase) of the parent wild-type strain, suggesting the limiting-step for the synthesis of $4 \mathrm{HB}$-containing PHA is the PHA synthase rather than the enzyme responsible from the generation of $4 \mathrm{HB}-\mathrm{CoA}$ from $4 \mathrm{HB}$. Such pattern is different from the understandings on the production of $\mathrm{P} 3 \mathrm{HB}$ in $C$. necator in which, instead, the reaction catalyzed by the acetoacetyl-CoA reductase is the rate-determining reaction (Doi et al., 1992). Expression of additional copies of the genes encoding 
$\mathrm{PhaC}_{\mathrm{Ca}}$ and $\beta$-ketothiolase in C. acidovorans JCM10181 resulted in twice-higher $\mathrm{P} 4 \mathrm{HB}$ content, from 33 to $63 \mathrm{wt} \%$ from 4hydroxybutyric acid (Sudesh et al., 1999). The genes were cloned in a multi-copy plasmid under the control of the strong hybrid $t r c$ promoter, $\mathrm{PhaC}$ and $\beta$-ketothiolase activities were significantly increased. In analogy to findings by Steinbüchel et al. (1994), increased PhaC activity resulted in higher $\mathrm{P} 4 \mathrm{HB}$ accumulation. 4-hydroxybutyric acid, a controlled pro-drug, often used as substrate for $\mathrm{P} 4 \mathrm{HB}$ production is costly. Knowing the substrate cost represents nearly $50 \%$ of the total cost for PHA production (Ahn et al., 2000), 1,4-BDO was used as the starting material to obtain $4 \mathrm{HB}$ for $\mathrm{P} 4 \mathrm{HB}$ homopolymer production in recombinant Aeromonas hydrophila 4AK4, E. coli S17-1, or Pseudomonas putida KT2442 (Zhang et al., 2009). In this study, 1,4-BDO was converted to $4 \mathrm{HB}$ by bacterial cells harboring 1,3-propanediol dehydrogenase gene dhaT and aldehyde dehydrogenase gene aldD from $P$. putida KT2442. Ten $\mathrm{g} \mathrm{L}^{-1} 4 \mathrm{HB}$ was obtained from $20 \mathrm{~g} \mathrm{~L}^{-1}$ of 1,4 -BDO after $52 \mathrm{~h}$ of cultivation of recombinant A. hydrophila in a $6 \mathrm{~L}$ fermenter (Zhang et al., 2009). Afterward, this $4 \mathrm{HB}$ containing fermentation broth was sterilized and added to minimum or complex media for the production of $\mathrm{P} 4 \mathrm{HB}$ and $\mathrm{P}(3 \mathrm{HB}-c o-4 \mathrm{HB})$ in recombinants E. coli XL1-Blue and $C$. necator $\mathrm{H} 16$, respectively. Here, the necessary twostep fermentation was time consuming and complicated the production process. Moreover, the conversion rate of $1,4-\mathrm{BDO}$ was rather low.

Hein et al. (1997) reported the first synthesis of P4HB homopolymer in recombinant E. coli. Strains of E. coli have been extensively genetically engineered and used in industry for the production of several bioproducts (Katz et al., 2018). Moreover, wild-type E. coli is not capable of synthesizing PHA. Thus, the absence of endogenous genes involved in the synthesis of PHA opens possibilities to control PHA monomer composition. The core of the recombinant system of Hein et al. (1997) was the heterologous expression of a gene cluster from the Gram-positive and anaerobic bacterium Clostridium kluyveri comprising an open reading frame (ORF) of a putative 4hydroxybutyril-CoA transferase (OrfZ). This ORF was identified in the studies of Söhling and Gottschalk on the molecular aspects of the succinate degradation pathway of C. kluyveri involved in the unusual cofermentation of ethanol and succinic acid in this bacterium in which 4-hydroxybutyril-CoA is an intermediate (Söhling and Gottschalk, 1996). The work consisted on the construction of a genomic library of C. kluyvery using E. coli as host strain and selection of the clones able to oxidize 4-hydroxybutyrate were selected. A gene region of 6'575 bp was obtained having several ORFs for proteins including succinate semialdehyde dehydrogenase (sucD), 4hydroxybutyric acid dehydrogenase $(4 h b D)$, succinyl-CoA:CoA transferase (cat1), a putative membrane protein (orf $Y$ ), and OrfZ with unknown function by then. In this pathway, CoA is transferred to succinate by CAT1. After, succinyl-CoA is reduced to succinic semialdehyde and CoA in a reaction catalyzed by SucD. Succinic semialdehyde is reduced to 4-hydroxybutyrate by $4 \mathrm{HbD}$ followed by $\mathrm{CoA}$ activation to $4 \mathrm{HB}-\mathrm{CoA}$ catalyzed by OrfZ (Valentin and Dennis, 1997). Hein et al. further used E. coli XL1-Blue to express phaC of C. necator and orfZ of
C. kluyvery (Figure 2) in a plasmid called pKSSE5.3 resulting in the synthesis of $\mathrm{P} 4 \mathrm{HB}$ homopolymer in a shake flask cultivation. $\mathrm{P} 4 \mathrm{HB}$ accumulation of up to $58.5 \%$ of its cell dry weight was achieved when 4-hydroxybutyric acid and glucose were fed to the cells. Along with the publication in 1997, a patent was filed by Monsanto Company [publication number: WO199839453 (Hein et al., 1998)]. Some years later in a sequence of studies, $\mathrm{P} 4 \mathrm{HB}$ synthesis in E. coli using the same plasmid system was further improved via bioprocess optimization. A P4HB content of up to $70 \mathrm{wt} \%$ was achieved in single stage batch cultures of $E$. coli JM109 harboring pKSSE5.3 using sodium-4-hydroxybutyrate and xylose as carbon sources (Le Meur et al., 2013). Sodium4-hydroxybutyrate was obtained from chemical hydrolysis of $\gamma$-butyrolactone for production of $\mathrm{P} 4 \mathrm{HB}$ in recombinant $E$. coli. The cost for $\gamma$-butyrolactone is 250 -fold lower than that of 4 hydroxybutyric acid, thus, substantially reducing the production costs. $\mathrm{P} 4 \mathrm{HB}$ productivity was also largely improved when exponential feeding of a solution composed by glycerol, acetic acid, and sodium-4-hydroxybutyrate was employed in a fedbatch cultivation employing the same recombinant E. coli strain (Le Meur et al., 2014). Amino acid limitation rather than nitrogen limitation was observed to prompt PHA production, thus the addition of a weak organic acid such as acetic acid was strategically supplemented to artificially create an amino acid limitation. As an alternative to acetic acid, the addition of propionic acid along with glycerol and sodium4-hydroxybutyrate also improved $\mathrm{P} 4 \mathrm{HB}$ production in batch cultures resulting in a polymer content of $80 \mathrm{wt} \%$ in cell biomass (Kampf et al., 2014). The increase in P4HB accumulation, however, was accompanied by a reduction in residual biomass. Further, the addition of methionine weakened the effect of propionic acid on $\mathrm{P} 4 \mathrm{HB}$ synthesis. Therefore, supplementation of propionic acid was suggested to enhance $\mathrm{P} 4 \mathrm{HB}$ production by decreasing the intracellular pool of methionine, which results in cell growth inhibition. The consequent increase of acetyl-CoA availability is thought to be the reason for the improved synthesis of $\mathrm{P} 4 \mathrm{HB}$ by recombinant $E$. coli.

Halophilic bacteria, which grow in the presence of high concentration of salts, are potential hosts for reducing the costs of PHA production since they can be cultivated continuously under unsterile conditions. In 2017, Chen et al. engineered the marine $\mathrm{P} 3 \mathrm{HB}$ producer Halomonas bluephagenesis TD01 for the production of $\mathrm{P}(3 \mathrm{HB}-\mathrm{co}-4 \mathrm{HB})$ (Chen et al., 2017). The orf $Z$ gene from $C$. kluyveri under the control of constitutive tac promoter was integrated into the genome of $H$. bluephagenesis TD01. Recombinant bacterium was cultivated in a medium with glucose and $\gamma$-butyrolactone as $\mathrm{C}$ sources. Sterilization was not necessary and tap water was used during the whole process. In pilot-scale (1000 L), 61 wt $\%$ of $\mathrm{P}(3 \mathrm{HB}-\mathrm{co}-16 \mathrm{~mol} \% 4 \mathrm{HB})$ were accumulated in the cells with a productivity of $1.04 \mathrm{~g} \mathrm{~L}^{-1} \mathrm{~h}^{-1}$. In a follow up publication (Ye et al., 2018b), H. bluephagenesis TD01 was further modified by the deletion of its succinate semialdehyde dehydrogenase gene $(g a b D)$ resulting in the strain TD40 (Figure 2). Glucose, $\gamma$-butyrolactone, and waste corn steep liquor were used as carbon sources for growth and polymer production. The non-sterile fed-batch fermentation was scaledup to a $5 \mathrm{~m}^{3}$ vessel resulting in a cell dry weight of $100 \mathrm{~g} \mathrm{~L}^{-1}$ and 


\section{Metabolic pathway of $4 \mathrm{HB}$} structurally-related C-sources

4-hydroxybutyric acid, $\gamma$-butyrolactone,

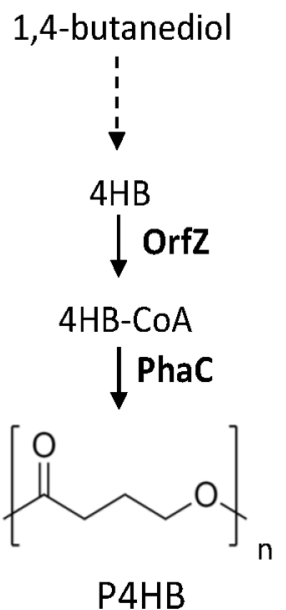

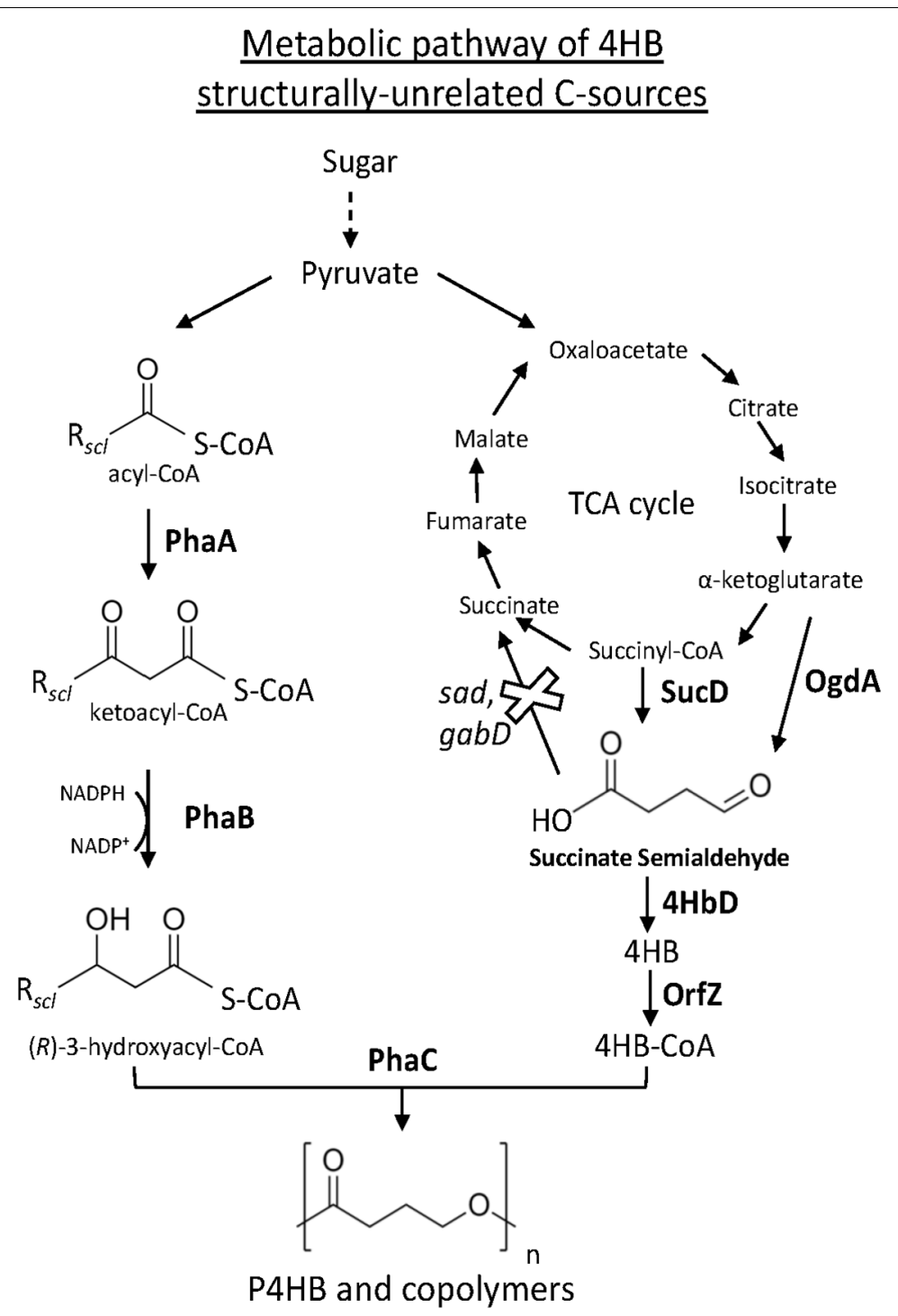

Metabolic pathway of $4 \mathrm{HB}$ structurally-unrelated C-sources

FIGURE 2 | Metabolic pathway heterologously expressed in recombinant bacteria (e.g., E. coli and $H$. bluephagenesis) for the synthesis of P4HB and copolymers from related and unrelated $C$ sources. The deletion of endogenous sad and gabD both encoding succinate semialdehyde dehydrogenase reinforces the carbon flux toward 4HB-CoA. PhaA, 3-ketothiolase; PhaB, acetoacetyl-CoA reductase; OgdA, 2-oxo-glutarate dehydrogenase; SucD, succinate semialdehyde dehydrogenase; 4HbD, 4-hydroxybutyrate dehydrogenase; OrfZ, 4HB-CoA transferase; PhaC: PHA synthase.

accumulation of up to $74 \mathrm{wt} \%$ of $\mathrm{P}(3 \mathrm{HB}-\mathrm{co}-13.5 \mathrm{~mol} \% 4 \mathrm{HB})$ after $36 \mathrm{~h}$ of cultivation.

\section{Production of P4HB Copolymers From Unrelated Carbon Sources in Recombinant Bacteria}

The first report on the biosynthesis of $4 \mathrm{HB}$ copolymers from unrelated carbon sources was published in Valentin and Dennis (1997). The heterologous expression of genes encoding for SucD, $4 \mathrm{HbD}$, and OrfZ from C. kluyveri, along with the genes of the PHA operon of C. necator was attempted in E. coli (Figure 2). Even though the lac promoter was placed upstream the succinate degradation genes, results suggested that the genes were not under the control of this promoter. Using solely glucose as C source, recombinant $E$. coli accumulated up to $46 \mathrm{wt} \%$ of
$\mathrm{P}(3 \mathrm{HB}-\mathrm{co}-4 \mathrm{HB})$ with no more than $2.8 \mathrm{~mol} \% 4 \mathrm{HB}$. This study indicated that $4 \mathrm{HB}-\mathrm{CoA}$ is likely to be generated from succinyl$\mathrm{CoA}$, an intermediary of the tricarboxylic acid cycle (TCA). Improved $4 \mathrm{HB}$ incorporation was achieved by further modifying E. coli (Li et al., 2010). The strong and constitutive pyruvate decarboxylase promoter $\left(\mathrm{P}_{p d c}\right)$ of Zymomonas mobilis led the transcription of $s u c D$ and $4 \mathrm{hbD}$ from $C$. kluyveri cloned in a plasmid. Moreover, to hamper the formation of succinate from succinate semialdehyde and reinforce the carbon flux to $4 \mathrm{HB}-$ CoA, E. coli native succinate semialdehyde dehydrogenase genes sad and gabD were deleted (Figure 2). Expression of PHA operon genes from $C$. necator and orfZ from $C$. kluyvery was driven by the respective native promoters. From glucose and with the addition of $\alpha$-ketoglutarate or citrate for incrementing $4 \mathrm{HB}-\mathrm{CoA}$ 
generation, recombinant $E$. coli accumulated up to $65.5 \mathrm{wt} \%$ of $\mathrm{P}(3 \mathrm{HB}-\mathrm{co}-4 \mathrm{HB})$ with a $4 \mathrm{HB}$ fraction as high as $20 \mathrm{~mol} \%$.

With the motivation to synthesize $\mathrm{P}(3 \mathrm{HB}-\mathrm{co}-4 \mathrm{HB})$ in plants, $\gamma$-aminobutyrate (GABA) and glutamate as precursor substrates were evaluated in recombinant E. coli (Valentin et al., 2000). The use of plants was considered to be less expensive than bacteria, however, succinyl-CoA is not found at high levels in the plastidial stroma. Glutamate, on the other hand, is an important intermediate of amino acid metabolism in plants. Furthermore, by the decarboxylation of glutamate, catalyzed by glutamate dehydrogenase existing in plants, GABA is generated. GABA is typically degraded via a transaminase reaction resulting in succinic acid semialdehyde that is further oxidized by a succinic acid semialdehyde dehydrogenase to succinate. The genes heterologously expressed by E. coli CT101 encoded for glutamate decarboxylase (without calmodulin-binding site) from Arabidopsis thaliana, glutamate:succinic semialdehyde transaminase and 4-hydroxybutyrate dehydrogenase from C. necator, OrfZ from C. kluyveri, and $\mathrm{PhaA} / \mathrm{PhaB} / \mathrm{PhaC}$ of C. necator. Escherichia coli CT101 does not have $\mathrm{NAD}^{+}$dependent succinic semialdehyde dehydrogenase, reducing the competition with 4-hydroxybutyrate dehydrogenase for succinic semialdehyde. Less than 5\% of PHA containing up to $5 \mathrm{~mol} \%$ $4 \mathrm{HB}$ was accumulated in the cells fed with glutamate or GABA. It demonstrates that $4 \mathrm{HB}-\mathrm{CoA}$ can be generated from glutamate or GABA, however, the metabolic flux in the expressed metabolic pathway was likely to be not enough for the production of higher amounts of $\mathrm{P}(3 \mathrm{HB}-\mathrm{co}-4 \mathrm{HB})$.

Due to the capability to use sunlight as energy source and $\mathrm{CO}_{2}$ as the C source, the cyanobacteria Synechococcus sp. PCC 7002 was genetically modified to produce copolymers containing $4 \mathrm{HB}$ (Zhang et al., 2015), as an alternative production strain to potentially reduce the costs of production. Since succinic semialdehyde is an intermediate in the TCA cycle variant of cyanobacteria, the possibility of $4 \mathrm{HB}-\mathrm{CoA}$ formation from it was investigated. First, the phaABEC operon composed by enzymes for P3HB production from Chlorogloeopsis fritschii PCC 9212 was introduced in Synechococcus sp. PCC 7002. To avoid the possibility of homologous recombination with the heterologous genes, the operon encoding 2-oxoglutarate decarboxylase and succinic semialdehyde dehydrogenase was deleted as well as the ccmc gene (Daley et al., 2012). Lastly, the construct encoding the biosynthetic pathway for $4 \mathrm{HB}-\mathrm{CoA}$ from succinic semialdehyde comprising 2-oxoglutarate decarboxylase from Synechococcus sp. PCC7002, 4-hydroxybutyrate dehydrogenase, and 4-hydroxybutyryl-CoA transferase from Porphyromonas gingivalis W83, replaced the chromosomal malate dehydrogenase gene by homologous recombination. From $\mathrm{CO}_{2}$, recombinant Synechococcus sp. PCC 7002 could accumulate $4.5 \% \mathrm{P}(3 \mathrm{HB}-$ co$12 \mathrm{~mol} \% 4 \mathrm{HB}$ ) of its cell dry weight.

Aiming at the synthesis of $4 \mathrm{HB}$ copolymers in $H$. bluephagenesis TD01 from glucose, a metabolic pathway was designed for the generation of succinate semialdehyde as direct $4 \mathrm{HB}-\mathrm{CoA}$ precursor from both 2-oxoglutarate, mediated by 2-oxo-glutarate dehydrogenase (OgdA), and succinyl-CoA, catalyzed by SucD, known intermediates of the TCA cycle (Ye et al., 2018a). The genes sucD, 4hbD, and orfZ from
C. kluyveri and ogdA from Synechococcus sp. PCC 7002 were then expressed in $H$. bluephagenesis (Figure 2); however, only $0.17 \mathrm{~mol} \% 4 \mathrm{HB}$ was incorporated in the polymer produced by this strain. Putative succinate semialdehyde dehydrogenases of $H$. bluephagenesis TD01 were found to deviate the carbon flux by converting succinate semialdehyde to succinate. Among the five putative succinate semialdehyde dehydrogenases identified, double deletion of gabD2 and gabD3 increased 24-fold the 4HB fraction, while the deletion of the respective five genes did not further increase the incorporation of $4 \mathrm{HB}$. In a batch cultivation, the double knockout mutant accumulated up to $60.5 \mathrm{wt} \%$ of $\mathrm{P}(3 \mathrm{HB}-\mathrm{co}-4 \mathrm{HB})$ with a maximum of $25 \mathrm{~mol} \% 4 \mathrm{HB}$ from glucose.

\section{Production of P4HB Homopolymer From Unrelated Carbon Sources in Recombinant Bacteria}

In 2004, Metabolix Inc., a company founded by Oliver P. Peoples and Antony Sinskey from the Massachusetts Institute of Technology (MIT), patented the invention of synthesis of PHA containing $4 \mathrm{HB}$, including $\mathrm{P} 4 \mathrm{HB}$ homopolymer, by transgenic organisms (Huisman et al., 2002). This patent describes the generation of transgenic microorganisms, e.g., E. coli, and plants by the integration of genes needed for the production of $4 \mathrm{HB}$ containing PHAs on the chromosome. The expression of genes of interest is sufficient and stable once the transcriptional and translational signals preceding the genes were optimized. It is also claimed that the use of inexpensive carbon sources (e.g., glucose, sucrose, xylose, and lactose) is enhanced by increasing enzyme activities in the $\gamma$-hydroxybutyrate shunt. At the same time, reducing the activity of enzymes that drain the intermediates of 4-hydroxybutyric acid from this shunt is reduced. Moreover, methods to redirect the cellular metabolite succinic acid to 4hydroxybutyric acid were also developed. Because engineered E. coli $\mathrm{K} 12$ has been characterized for production of medical compounds and it is highly efficient, to the best of our knowledge, $50 \mathrm{~g} \mathrm{~L}^{-1}$ of polymer is produced in less than $48 \mathrm{~h}$ (Martin and Williams, 2003). This strain is used for the production of $\mathrm{P} 4 \mathrm{HB}$, which is commercialized with the tradename TephaFLEX ${ }^{\circledR}$. In 2016, the producer of TephaFLEX ${ }^{\circledR}$, Tepha Inc. (Cambrigde, MA, United States), completed a buyout of its royalty obligation to Metabolix Inc., making Tepha Inc. the current patent-holder of US6689589. ${ }^{1}$

Zhou et al. (2012) reported hyperproduction of P4HB homopolymer from unrelated $\mathrm{C}$ source, i.e., glucose, in a recombinant strain. Escherichia coli JM109 with knocked out native genes (sad, gabD) encoding succinate semialdehyde dehydrogenase, heterologously expressed in plasmids the genes encoding for succinate degradation enzymes $(s u c D, 4 h b D$, and orfZ) of C. kluyveri and PhaC of C. necator (Figure 2). In addition, individual expression of four phasins of $C$. necator (phaP1, phaP2, phaP3, and phaP4) and their effect on the synthesis of $\mathrm{P} 4 \mathrm{HB}$ was investigated. Phasins are proteins located on the surface of PHA granules and participate in the regulation of surface/volume ratio of the granules but also interacting with the PHA synthase. Among the four phasins, PhaP1, followed by

\footnotetext{
${ }^{1}$ https://www.tepha.com/news-events/press-releases/post/august-31st-2016tepha-inc-announces-buy-royalty-obligation-metabolix-inc/
} 
PhaP3, led to the highest PHA accumulation. Up to $68.2 \mathrm{wt} \%$ of $\mathrm{P} 4 \mathrm{HB}$ was accumulated from glucose in recombinant $E$. coli expressing phaP1 (Zhou et al., 2012). Indeed, PhaP1 is the major phasin of C. necator (Pötter et al., 2005). Single knockout of phaP1 significantly decreased $\mathrm{P} 3 \mathrm{HB}$ accumulation while the single knockout mutants of phaP2, phaP3, and phaP4 had similar accumulation to the wild-type C. necator H16 (Pötter et al., 2005). To summarize, Table 3, exhibits patents on the biosynthesis of $\mathrm{P} 4 \mathrm{HB}$ and copolymers.

\section{Monomer Composition and Microstructure Control of $\mathrm{P}(3 \mathrm{HB}-\mathrm{CO}-4 \mathrm{HB})$}

Clustered regularly interspaced short palindromic repeats interference (CRISPRi) was evaluated as a strategy to adjust the monomer composition of $\mathrm{P}(3 \mathrm{HB}-$ co- $4 \mathrm{HB})$ using solely glucose as C source (Lv et al., 2015). The CRISPR/Cas system comprises a Cas9 endonuclease and a single guide RNA ( $s g$ RNA) complementary to a genomic target sequence. This system generates a double strand break at a specific site of the genome, a feature that has been extensively used for gene editing in bacteria and eukaryotic cells. In CRISPRi, Cas9 has its endonuclease function inactivated (dCas9), but it still binds to a target genome loci directed by the sgRNA. Gene transcription can be blocked by the binding of dCas9-sgRNA complex to the upstream region of the gene (Cho et al., 2018). Escherichia coli was engineered to express the genes from C. necator PHA operon and orfZ, sucD, and $4 h b D$ from $C$. kluyreri. The E. coli genes encoding succinylCoA synthetase (sucC and sucD), succinate dehydrogenase ( $s d h A$ and $s d h B$ ), and succinyl-CoA synthetase (sad) were individually, in pairs, or simultaneously downregulated using the CRISPRi

TABLE 3 | Patented methods for the production of PHAs containing 4HB.

\begin{tabular}{|c|c|c|}
\hline Publication number & Content & References \\
\hline WO2018233703 & $\begin{array}{l}\text { Gene cassette for fine control } \\
\text { of composition ratio of } \\
\text { 4-hydroxybutanoic acid in } \\
\text { copolymer and application } \\
\text { thereof }\end{array}$ & Li et al., 2018 \\
\hline WO2014058655 & $\begin{array}{l}\text { Polyhydroxyalkanoate } \\
\text { copolymer compositions } \\
(3 \mathrm{HB}-\mathrm{co}-4 \mathrm{HB}) \text { and methods } \\
\text { for making the same }\end{array}$ & Ramseier et al., 2014 \\
\hline US6689589 & $\begin{array}{l}\text { Biological systems for } \\
\text { manufacture of } \\
\text { polyhydroxyalkanoate } \\
\text { polymers containing } \\
\text { 4-hydroxyacids }\end{array}$ & Huisman et al., 2002 \\
\hline US6117658 & $\begin{array}{l}\text { Methods of making } \\
\text { polyhydroxyalkanoates } \\
\text { comprising } \\
\text { 4-hydroxybutyrate monomers } \\
\text { units }\end{array}$ & Dennis and Valentin, 2000 \\
\hline WO1998039453 & $\begin{array}{l}\text { Methods for the biosynthesis } \\
\text { of polyesters }\end{array}$ & Hein et al., 1998 \\
\hline W01997007153 & $\begin{array}{l}\text { Methods for controlling } \\
\text { microbial polyester structure } \\
\text { by the addition of } \\
\text { polyethylene glycol (PEG) }\end{array}$ & Gross et al., 1997 \\
\hline
\end{tabular}

system in order to strengthen the carbon flux in E. coli toward $4 \mathrm{HB}-\mathrm{CoA}$ synthesis. $4 \mathrm{HB}$ fraction in the polymer increased, as more genes were downregulated simultaneously. Reduced expression of all five genes resulted in the highest $4 \mathrm{HB}$ fraction of more than $18 \mathrm{~mol} \%$.

Pseudomonas putida KTOY08 $\Delta \mathrm{GC}$, a weakened $\beta$-oxidation mutant of $P$. putida KT2242 having the genes encoding PHA synthase $(p h a C)$ and 3-hydroxyacyl-CoA-acyl carrier protein transferase $(p h a G)$ knocked out, was used as host strain aiming at the synthesis of PHA block copolymers of $3 \mathrm{HB}$ and $4 \mathrm{HB}$ (Hu et al., 2011). Due to microphase separation of PHA blocks with distinguished physical properties, structurally controlled PHAs as such can present novel properties compared to random and blend copolymers. The synthesis of which, however, is not trivial. Pseudomonas putida KTOY08 $\Delta$ GC was modified to express phaC of $C$. necator and C. kluyveri orfZ. Because of its reduced $\beta$-oxidation metabolism, this strain was able to use sodium-butyrate and $\gamma$-butyrolactone for PHA production more efficiently. Sequential feeding of both substrates was the strategy used for making PHA block copolymers. In a cultivation in LB medium, $\gamma$-butyrolactone was added at 12 and $36 \mathrm{~h}$ of cultivation leading to the formation of $\mathrm{P} 4 \mathrm{HB}$. Sodium-butyrate was fed to the cells at $60 \mathrm{~h}$ and the fermentation proceeded for another $48 \mathrm{~h}$ with the formation of the second block composed of pure $3 \mathrm{HB}$. The block structure of the PHA with $80 \mathrm{~mol} \% 4 \mathrm{HB}$ was assessed by NMR analyses and the thermal and mechanical properties of the polymer were also examined.

\section{DOWNSTREAM PROCESSING OF P4HB}

The downstream processing (DSP) of PHAs, which comprises the recovery of $\mathrm{PHA}$-containing biomass from the cultivation broth until the final polymer at a certain level of purity depending on the material applications, is one of the most expensive steps of PHA production. However, little progress has been observed compared to the innovations on metabolic engineering and bioprocess. In order to separate PHA from cell components (e.g., cell envelope, nucleic acids, and peptides) and from PHA granule-associated proteins, appropriate extraction processes must be applied. Different processes have been investigated and established in the past. The conventional method involves an organic solvent to extract the water insoluble polymer from dry biomass, which is then precipitated in a non-solvent resulting in the removal of also oligomers and monomers. The treatment of the cells with an aqueous mixture of chemical agents (e.g., $\mathrm{NaOH}$ and $\mathrm{KOH}$ ) and/or enzymes to lyse bacteria obtaining PHA as latex is also commonly used. Jacquel et al. (2008) and others Furrer et al. (2007) have published an excellent summary of the different extraction methods for PHAs. The often-used solvents to recover PHAs from freeze-dried biomass include chloroform, methylene chloride, tetrahydrofuran methyl anhydride, tetrahydrofuran ethyl cyanide, and others were tested. Although the solvent extraction method is able to give a high level of purity, it is difficult to separate solubilized PHA from nonPHA cell materials when only filtration is applied. Even though pressure can be applied, the separation often takes a long time 
and filters are often blocked. Extraction using organic solvents results in PHA with higher purity than when aqueous treatment is employed. A key factor to the application of PHAs in medicine is the appropriate removal of contaminating pyrogenic compounds, which can cause inflammation and fever in humans. The endotoxins (lipopolysaccharides) are the components of the outer cell membrane of Gram-negative production strains (Petsch and Anspach, 2000). The United States Pharmacopeia (USP) sets as a threshold an upper limit of 20 endotoxin units (EU) per medical device, and 2.15 EU per device that contacts the cerebrospinal fluid (F.D.A., 1997). Lee et al. (1999) compared chloroform extraction and $\mathrm{NaOH}$ digestion method for recovering $\mathrm{P} 3 \mathrm{HB}$ from cells of gram-negative bacteria (C. necator, A. latus, and recombinant $E$. coli) concerning the removal of endotoxins. $\mathrm{P} 3 \mathrm{HB}$ obtained from the chloroform extraction method by the addition of 50 volumes of chloroform and incubation at $30^{\circ} \mathrm{C}$ from $48 \mathrm{~h}$ resulted in less than $10 \mathrm{EU}$ per $\mathrm{g}$ of $\mathrm{P} 3 \mathrm{HB}$ (Lee et al., 1999). By using the $\mathrm{NaOH}$ digestion method at $30^{\circ} \mathrm{C}$, either 0.2 $\mathrm{N} \mathrm{NaOH}$ for $5 \mathrm{~h}$ or a $\mathrm{NaOH}$ concentration higher than $2 \mathrm{~N}$, polymer with less than $1 \mathrm{EU}$ per $\mathrm{g}$ was recovered (Lee et al., 1999). A temperature-controlled precipitation method (Furrer et al., 2007) as well as the addition of active charcoal at the beginning of polymer extraction with ethyl acetate (Wampfler et al., 2010) have also been reported to lead the recovery of $m c l$-PHAs synthesized in $P$. putida species with less than 2 EU per $g$ of polymer.

Most of the methods depicted in Table 4, have been mainly developed to isolate and purify scl-PHAs such as $\mathrm{P} 3 \mathrm{HB}$ and $\mathrm{P}(3 \mathrm{HB}-\mathrm{co}-3 \mathrm{HV})$. Thus, the same methods can be extrapolated for the purification of $\mathrm{P} 4 \mathrm{HB}$ as well. All these methods have both advantages and disadvantages. To the best of our knowledge, methods for $\mathrm{P} 4 \mathrm{HB}$ extraction have been mainly solvent-based from freeze-dried biomass. Due to the disadvantages of the solvent extraction method, development of cost-efficient, easy-tohandle, scalable, and eco-efficient process for $\mathrm{P} 4 \mathrm{HB}$ purification is indispensable for enlarging the use of this polymer in diverse applications.

\section{MATERIAL PROPERTIES OF P4HB}

P4HB is a strong thermoplastic (i.e., it is moldable when heated and hard at room temperature) and significantly more flexible than synthetic resorbable polymers such as PGA and poly-Llactide (PLLA). Its tensile strength is comparable to ultra-high molecular weight polyethylene and an elongation at break of around $1000 \%$ (Martin and Williams, 2003). After stretching $\mathrm{P} 4 \mathrm{HB}$, the mechanical strength increases but the material remains flexible. The same does not occur with PGA or PLLA, which mechanical strength rises along with polymer brittleness (Williams et al., 2016). As for other polymers, the processing history of the material influences the mechanical properties. The mechanical strength of $\mathrm{P} 4 \mathrm{HB}$ increases to a large extend with the orientation of the fibers produced though conventional melt spinning processes and which can be further processed using textile methods such as braiding, knitting and weaving. Compression molded $\mathrm{P} 4 \mathrm{HB}$ films, on the other hand, presents high elongation at break similar to polycaprolactone (PCL)
TABLE 4 | Patents for downstream processing of PHA.

\begin{tabular}{|c|c|c|}
\hline Publication number & Brief description & References \\
\hline US20190127727A1 & $\begin{array}{l}\text { Application of } \\
\text { high-voltage pulsed } \\
\text { electric field to the waste } \\
\text { sludge during the } \\
\text { extraction step to destroy } \\
\text { the microorganisms and } \\
\text { release the PHAs }\end{array}$ & Tsai et al., 2019 \\
\hline WO2005052175A2 & $\begin{array}{l}\text { Process for recovering } \\
\text { PHAs from cellular } \\
\text { biomass using } \\
\text { non-halogenated } \\
\text { compounds }\end{array}$ & Mantelatto et al., 2005 \\
\hline WO2006031492A1 & $\begin{array}{l}\text { Single solvent polymer } \\
\text { extraction methods }\end{array}$ & Anderson et al., 2006 \\
\hline US2005287654A1 & $\begin{array}{l}\text { Process for the } \\
\text { solvent-based extraction } \\
\text { of polyhydroxyalkanoates } \\
\text { from biomass }\end{array}$ & Narasimhan et al., 2005 \\
\hline US2001006802A1 & $\begin{array}{l}\text { Methods for separation } \\
\text { and purifying } \\
\text { polyhydroxyalkanoates }\end{array}$ & Horowitz and Brennan, 2001 \\
\hline US6087471 & $\begin{array}{l}\text { High temperature PHA } \\
\text { extraction using } \\
\text { PHA-poor solvents }\end{array}$ & Kurdikar et al., 2000 \\
\hline US5894062 & $\begin{array}{l}\text { Process for the recovery } \\
\text { of polyhydroxyalkanoic } \\
\text { acid }\end{array}$ & Liddell, 1999 \\
\hline W09846782A1 & $\begin{array}{l}\text { Methods of PHA } \\
\text { extraction and recovery } \\
\text { using non-halogenated } \\
\text { solvents }\end{array}$ & Kurdikar et al., 1998 \\
\hline US5821299 & $\begin{array}{l}\text { Solvent extraction of } \\
\text { polyhydroxy-alkanoates } \\
\text { from biomass facilitated } \\
\text { by the use of marginal } \\
\text { nonsolvent }\end{array}$ & Noda, 1998b \\
\hline US5849854 & $\begin{array}{l}\text { Process for recovering } \\
\text { polyhydroxyalkanotes } \\
\text { using air classification }\end{array}$ & Noda, 1998a \\
\hline W09707230A1 & $\begin{array}{l}\text { Solvent extraction of } \\
\text { polyhydroxy-alkanoates } \\
\text { from biomass }\end{array}$ & Noda and Schechtman, 1997 \\
\hline US4101533 & $\begin{array}{l}\text { Cyclic carbonic acid } \\
\text { esters as solvents for } \\
\text { poly- }(\beta) \text {-hydroxybutyric } \\
\text { acid }\end{array}$ & Lafferty and Heinzle, 1978 \\
\hline US3044942 & $\begin{array}{l}\text { Process for preparing } \\
\text { poly- } \beta \text {-hydroxybutyric } \\
\text { acid }\end{array}$ & Noel, 1962 \\
\hline
\end{tabular}

(Figure 1), but lower tensile strength than the aligned polymer chains in fibers (Williams et al., 2013). Another interesting feature of $\mathrm{P} 4 \mathrm{HB}$ is the possibility to modify the polymer properties in vivo by the incorporation of another monomer such as $3 \mathrm{HB}$ by the bacterial PHA synthase. For example, copolymers of $4 \mathrm{HB}$ and $3 \mathrm{HB}$ with a $4 \mathrm{HB}$ fraction of $20-35 \%$ are elastomeric which can extend and return with force (Martin and Williams, 2003). P4HB has a melting temperature $\left(T_{m}\right)$ of $60^{\circ} \mathrm{C}$ and a glass transition temperature $\left(T_{g}\right)$ of $-51^{\circ} \mathrm{C}$ (Table 2). When melted up to $200^{\circ} \mathrm{C}$ 
$\mathrm{P} 4 \mathrm{HB}$ is reasonably stable presenting only a moderate molecular mass loss (Martin and Williams, 2003). Kunioka and Doi (1990) investigated the thermal degradation in the range of 100 to $200^{\circ} \mathrm{C}$ for $\mathrm{P}(3 \mathrm{HB}-\mathrm{co}-\mathrm{HV})$ and $\mathrm{P}(3 \mathrm{HB}-c o-4 \mathrm{HB})$ with different monomer compositions of up to $71 \mathrm{~mol} \% \mathrm{HV}$ and $82 \mathrm{~mol} \% 4 \mathrm{HB}$, respectively. The polymers presented time-dependent changes in molecular weight following the kinetic model of random chain scission at ester groups and were considered thermally stable at temperatures up to $160^{\circ} \mathrm{C}$. The rates of random scission were independent on the polymer monomer composition but strongly dependent on temperature. Thus, $\mathrm{P} 4 \mathrm{HB}$ has a large thermo processing window and methods applicable to thermoplastics can be readily used to process $\mathrm{P} 4 \mathrm{HB}$ according to the desired shape, microstructure, and properties. Mitomo et al. have determined the amorphous density of $\mathrm{P} 4 \mathrm{HB}$ as 1.213 in comparison to 1.179 for $\mathrm{P} 3 \mathrm{HB}$. With this data, the heat of fusion, the necessary heat to melt the crystallites, could be calculated as $76 \mathrm{~J} \mathrm{~g}^{-1}$ for $\mathrm{P} 4 \mathrm{HB}$ and $125 \mathrm{~J} \mathrm{~g}^{-1}$ for $\mathrm{P} 3 \mathrm{HB}$ (Mitomo et al., 2001). The heat of fusion of P4HB is similar to that of PCL (78.1 J $\left.\mathrm{g}^{-1}\right)$. An enzymatic degradation assay of $\mathrm{P}(3 \mathrm{HB}-\mathrm{co}-4 \mathrm{HB})$ with various $4 \mathrm{HB}$ contents (0-90\%) was also performed using PHA depolymerase from Ralstonia pickettii $\mathrm{T} 1$. The polymer with $4 \mathrm{HB}$ fraction of 15 or $24 \%$ had the fastest degradation rate while the slowest degradation rate occurred using the polymer with $90 \%$ $4 \mathrm{HB}$. The degradation rate by the PHA depolymerase decreased with the decrease of polymer crystallinity and $3 \mathrm{HB}$ fraction.

\section{Molecular Mass Influences the Material Properties}

Since there are not many producers of $\mathrm{P} 4 \mathrm{HB}$, consequently it is difficult to obtain material samples for property analysis. Based on research studies, $\mathrm{P} 4 \mathrm{HB}$ synthesized in recombinant E. coli JM109 expressing pKSSE5.3 can result in ultra-high molecular mass $\left(M_{w} \sim 2.0-2.5 \times 10^{6} \mathrm{~g} \mathrm{~mol}^{-1}\right.$ ) (Boesel et al., 2014). Polymer processing via solvent- or melt-processing can be stunted by such high molecular weight. Further degradation by chemical method using a solution of sulfuric acid in methanol as catalyst added at every degradation time point for $16 \mathrm{~h}$ led to a change in properties and morphology (Figure 3; Boesel et al., 2014). P4HB degradation resulted in polymers with a $M_{w}$ ranging from $2.5 \times 10^{6}$ to $9.4 \times 10^{3} \mathrm{~g} \mathrm{~mol}^{-1}$ (Table 5). Interestingly, a decrease in molecular weight resulted in an increase in polymer crystallinity without an effect on neither melt nor glass transition temperatures. Moreover, both tensile strength and modulus decreased along with the decrease in molecular weight. Therefore, by carefully controlling $\mathrm{P} 4 \mathrm{HB}$ molecular weight the mechanical properties can be modified according to the envisioned applications.

\section{BIOCOMPATIBILITY AND BIODEGRADABILITY OF P4HB}

P4HB is known not only as cytocompatible but also very well tolerated in vivo (Martin and Williams, 2003). Indeed, the hydrolysis of $\mathrm{P} 4 \mathrm{HB}$ yields $4 \mathrm{HB}$ which is naturally found in the human body (i.e., brain, heart, lung, liver, kidney, and muscles) (Nelson et al., 1981). This metabolite has a half-life time of about $35 \mathrm{~min}$, and is degraded in the body via the Krebs cycle and subsequently converted to carbon dioxide and water (Sendelbeck and Girdis, 1985). Furthermore, since 4HB has a high $\mathrm{p} K_{a}\left[4.72\right.$ at $25^{\circ} \mathrm{C}$ (Lide, 2005)] and is prone to lactonization, it is less acidic than the $\alpha$-hydroxy acids such as glycolic $\left[\mathrm{p} K_{a} 3.83\right.$ at $25^{\circ} \mathrm{C}$ (Serjeant and Dempsey, 1979)] and lactic acid $\left[\mathrm{p} K_{a} 3.86\right.$ at $\left.20^{\circ} \mathrm{C}\left(\mathrm{O}^{\prime} \mathrm{Neil}, 2013\right)\right]$ that are released from PGA and PLLA implants, respectively. The pharmacology of $4 \mathrm{HB}$ is well understood (Martin and Williams, 2003). Sodium $4 \mathrm{HB}$, designated in the medical/pharmaceutical fields as sodium $\gamma$-hydroxybutyrate (GHB) or sodium oxybate, is a prescription medicine marketed as $\mathrm{Xyrem}^{\circledR}$ for the treatment of cataplexy attacks in patients with narcolepsy. The administration of $4.5 \mathrm{~g}$ of Xyrem ${ }^{\circledR} /$ night divided into two doses of $2.25 \mathrm{~g}$ with interval of $2.5-4 \mathrm{~h}$, with a medication increase of up to $9 \mathrm{~g}$ of Xyrem ${ }^{\circledR} /$ night has FDA clearance (Carter et al., 2009). However, 4HB itself is classified as a Schedule I substance by the FDA with no accepted medical use and high potential for abuse. ${ }^{2}$ Xyrem ${ }^{\circledR}$, on the other hand, is a Schedule III drug with moderate to low potential for physical or psychological dependence. ${ }^{2}$ In the last decades, the illicit use of $4 \mathrm{HB}$ as a "club drug" causing euphoria and relaxation is of major concern. On top of it, $4 \mathrm{HB}$ color- and odorless appearance facilitate the use for sedation (Drasbek et al., 2006). Amnestic and variable sedative effects are observed under low doses of $10-20 \mathrm{mg}^{4} \mathrm{HB} \mathrm{kg}^{-1}$ body weight while higher doses of $30-40 \mathrm{mg} \mathrm{kg}^{-1}$ or higher is reported to cause bradycardia, respiratory depression, and coma (van Noorden et al., 2016; Le and Richards, 2019). The effects become even more acute when $4 \mathrm{HB}$ is taken with other intoxicants, such as alcohol (Le and Richards, 2019). Due to the relatively slow rate of $\mathrm{P} 4 \mathrm{HB}$ degradation to $4 \mathrm{HB}$ and short half-life time of $4 \mathrm{HB}$ in the body, small $\mathrm{P} 4 \mathrm{HB}$ implants and devices are not expected to induce undesired pharmacological effects (Martin and Williams, 2003; Drasbek et al., 2006). Nevertheless, the biosynthesis of $\mathrm{P} 4 \mathrm{HB}$ from $4 \mathrm{HB}$ and structurally related $\mathrm{C}$ sources (e.g., $\gamma$-butyrolactone, 1,4-BDO) is not feasible in large scale and the research on it becomes limited for safety reasons.

It has been reported that $\mathrm{P} 4 \mathrm{HB}$ degrades more slowly than PGA, but faster than PLLA, and PCL in a non-specified subcutaneous environment (Martin and Williams, 2003). In one implantation study, for patch augmentation of the pulmonary artery in a juvenile sheep model, the loss of mass from the implanted $\mathrm{P} 4 \mathrm{HB}$ patch varied with surface porosity (Stock et al., 2000). Increasing porosity resulted in the increase of degradation rate, proposing that degradation of $\mathrm{P} 4 \mathrm{HB}$ in vivo depends to some extent on the contact area. Furthermore, it has been observed that implants of $\mathrm{P} 4 \mathrm{HB}$ are likely to undergo gradual changes in mechanical properties different from other synthetic absorbable polymers, for example PGA, in which the mechanical properties can be remarkably changed at sudden (Bostman, 1991). This also impacts on the slow and gradual release of $4 \mathrm{HB}$ in the blood, which avoids high acidification of the environment and accumulation of it in the body. In large PGA implants, on

\footnotetext{
${ }^{2}$ https://www.fda.gov/drugs/postmarket-drug-safety-information-patients-and-
} providers/xyrem-sodium-oxybate-information 


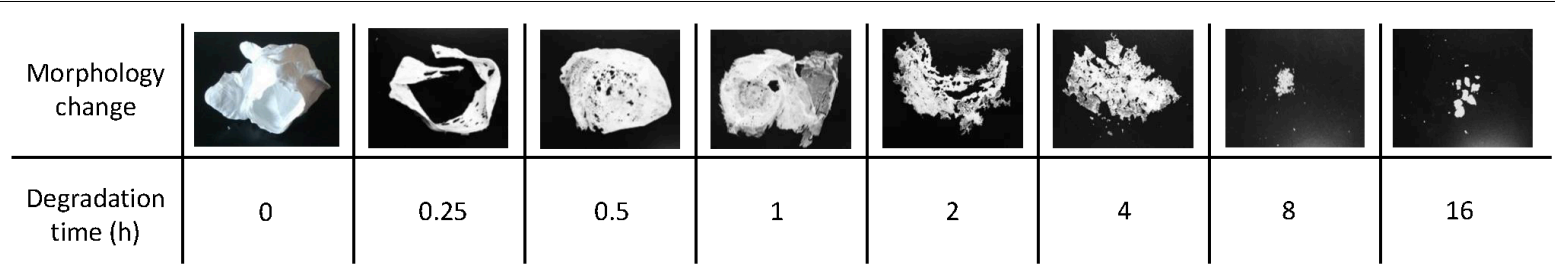

FIGURE 3 | P4HB morphological change along a polymer degradation assay using a solution of sulfuric acid in methanol as catalyst for $16 \mathrm{~h}$. Adapted from Boesel et al. (2014).

TABLE 5 | Molecular weights of P4HB after degradation by acidic methanolysis. Adapted from Boesel et al. (2014).

\begin{tabular}{|c|c|c|c|c|c|c|c|c|}
\hline \multirow[b]{2}{*}{ Molecular weight } & \multicolumn{8}{|c|}{ Degradation time (h) } \\
\hline & 0 & 0.25 & 0.5 & 1 & 2 & 4 & 8 & 16 \\
\hline$M_{n}\left(\mathrm{~g} \mathrm{~mol}^{-1}\right)$ & $872 ' 134$ & $292 ’ 365$ & 89’267 & $49^{\prime} 481$ & $30 ’ 245$ & $16^{\prime} 791$ & 9'940 & 6'006 \\
\hline$M_{w}\left(\mathrm{~g} \mathrm{~mol}^{-1}\right)$ & 2'500'000 & $917^{\prime} 588$ & $167 ’ 885$ & $92 ' 945$ & $54^{\prime} 780$ & $29^{\prime} 791$ & $17^{\prime} 446$ & $9^{\prime} 441$ \\
\hline
\end{tabular}

the other hand, a rapid loss of implant strength leading to the accumulation of highly acidic degradation products is likely to result in severe foreign body reactions (Bostman, 1991). Thus, P4HB's gradual biodegradability, which results in natural metabolites well tolerated in the body, gives to this material an in vivo stability status that is a major breakthrough in the fabrication of medical implants and scaffolds.

\section{APPLICATIONS OF P4HB}

$\mathrm{P} 4 \mathrm{HB}$ is a thermoplastic material that can be processed into various shapes and forms including fibers, films, tubes, foams, textiles, microspheres, and molded constructs using standard processing techniques [see review (Martin and Williams, 2003)]. Table 6 displays examples of patents on $\mathrm{P} 4 \mathrm{HB}$ in diverse medical applications.

\section{P4HB for Medical Implant Materials and of Regenerative Medicine}

A persisting challenge after the development of the first synthetic absorbable material for medical applications in 1970 was their extremely fast degradation in the body, thus a relatively short strength retention in vivo. Such polymers were successfully used in wound healing, but not as scaffolds for long-term reinforcement. After the FDA clearance of an absorbable monofilament suture in 2007, P4HB became the first longterm resorbable implant to enter the market in many years (Williams et al., 2016). Today, Tepha Inc. possesses 510(k) FDA clearance for medical devices made for their produced $\mathrm{P} 4 \mathrm{HB}$ and products are currently available in the United States and Europe. The portfolio of products made from TephaFLEX ${ }^{\circledR}$ polymer is composed by absorbable monofilaments (suture, mesh, and fiber), absorbable surgical film, and composite mesh are under development by Tepha Inc. absorbable multifilament fiber, absorbable knitted multifilament mesh, absorbable nonwoven textiles, cardiovascular absorbable stents and stent coatings from TephaFLEX ${ }^{\circledR}$ but also from their elastomeric absorbable
TephELAST $^{\circledR}$ polymer. $^{3}$ In collaboration with Tepha Inc., B. Braun Melsungen AG (Melsungen, Germany) fabricates Monomax $^{\circledR}$, a monofilament for synthetic suture. ${ }^{3}$ The use of $\mathrm{P} 4 \mathrm{HB}$ as medical implants has been extensively reviewed by Martin and Williams (2003) and Williams et al. (2013).

Tissue engineering aims at repairing damaged or replacing diseased tissues and organs. Tissues can be classified as hard tissues (bone and cartilage) and soft tissues (e.g., vascular and skin grafts). The biomaterial used should have mechanical properties for supporting the organ during tissue regeneration and own an appropriate surface topography for cell adhesion and proliferation (Rodriguez-Contreras, 2019). P4HB scaffolds are used for soft tissue support, concomitantly allowing robust tissue ingrowth. The material is resorbed in a predictable and steady manner (Williams et al., 2016). A wholly owned company of Tepha Inc., Galatea Surgical Inc. (Lexington, MA, United States) fabricates absorbable surgical scaffolds for soft tissue support and repair. ${ }^{4}$ Collaborators of Tepha Inc., C. R. Bard Inc. (New Jersey, United States) commercializes Phasix ${ }^{\mathrm{TM}}$ Mesh, a resorbable implant for soft tissue reconstruction and the absorbable scaffold BioFiber $^{\circledR}$ is commercialized by the Wright Medical Group Inc. (Memphis, Tennessee, United States)(see text footnote 3). In addition, the creation of a scaffold for a trileaflet heart valve made from $\mathrm{P} 4 \mathrm{HB}$ have also been reported. The scaffold functioned appropriately for 120 days in lambs, indicating the suitability of $\mathrm{P} 4 \mathrm{HB}$ for tissue engineering of heart valves (Sodian et al., 2000). Moreover, researchers of the University of Zürich and collaborators have been exploring the potential of $\mathrm{P} 4 \mathrm{HB}-$ based biomaterials and now have the approval for clinical studies. Stented trileaflet heart valves fabricated from PGA-P4HB composite matrices aiming at prenatal cardiac interventions (Weber et al., 2012), PGA-P4HB-based valves incorporated into metallic stents for cardiac and venous valve repair (Książek et al., 2016), and an anisotropic and porous 3D PGA microfibrillar scaffold coated with $\mathrm{P} 4 \mathrm{HB}$ to promote anisotropic cellular

\footnotetext{
${ }^{3}$ https://www.tepha.com/partnering/our-partners/
}

${ }^{4}$ https://www.galateasurgical.com/surgical-scaffolds/ 
TABLE 6 | Examples of patents on the applications of P4HB and copolymers thereof.

\begin{tabular}{|c|c|c|}
\hline Publication number & Content & References \\
\hline WO2015006737A1 & $\begin{array}{l}\text { Absorbable implants for } \\
\text { plastic surgery }\end{array}$ & Felix et al., 2015 \\
\hline WO2012142100A1 & $\begin{array}{l}\text { Biodegradable coextruded } \\
\text { multilayer films }\end{array}$ & Krishnaswamy, 2012 \\
\hline WO2008070428A2 & $\begin{array}{l}\text { Medical devices containing } \\
\text { oriented films of } \\
\text { poly-4-hydroxybutyrate and } \\
\text { copolymers }\end{array}$ & Rizk et al., 2008 \\
\hline WO2007092418A3 & $\begin{array}{l}\text { Polymeric, degradable } \\
\text { drug-eluting stents and } \\
\text { coatings comprising } \\
\text { copolymers or } \\
\text { homopolymers of } \\
\text { 4-hydroxybutyrate }\end{array}$ & Behrend et al., 2007 \\
\hline WO2006081517A2 & $\begin{array}{l}\text { Embolization of } \\
\text { poly-4-hydroxybutyrate } \\
\text { particles }\end{array}$ & Martin et al., 2006 \\
\hline WO2004101002A2 & $\begin{array}{l}\mathrm{P}(4 \mathrm{HB}) \text { fiber useful in } \\
\text { devices such as medical } \\
\text { textile, tube, general } \\
\text { surgical mesh, hernia } \\
\text { mesh, pericardial patch, } \\
\text { anti-adhesion patch }\end{array}$ & Martin et al., 2004 \\
\hline WO2001015671A2 & $\begin{array}{l}\text { Drug delivery devices or } \\
\text { bandages }\end{array}$ & Williams, 2001 \\
\hline WO2001019422A1 & $\begin{array}{l}\text { Polyhydroxyalkanoate } \\
\text { compositions for soft tissue } \\
\text { repair, augmentation, and } \\
\text { viscosupplementation }\end{array}$ & Williams and Martin, 2001 \\
\hline
\end{tabular}

organization for surgery and tissue engineering (Hosseini et al., 2018), are among the investigated biomaterials with promising applications.

\section{P4HB as Drug Delivery Carrier and Microspheres}

Biodegradable polymeric nanoparticles (NP), which are polymeric colloidal particles with their size ranging in one dimension from 1 to $100 \mathrm{~nm}$, have been studied for application in drug delivery (Som et al., 2019). The potential advantages are the controlled and sustained release of an encapsulated drug driven by a biodegradable and biocompatible material to its specific site. The use of such system can avoid side effects as observed in the treatment of tumors associated with multiple dosing of the drug (Duncan, 2006). Last but not least, nanoparticles cross the cellular membranes of body much easier than microparticles. Since $\mathrm{P} 4 \mathrm{HB}$ is an approved material for diverse medical applications in the United States and European countries, preparation and validation of NP for drug delivery from $\mathrm{P} 4 \mathrm{HB}$ is of high interest. Shah et al. (2014) reported the preparation of NPs from amphiphilic block copolymers of $\mathrm{P} 4 \mathrm{HB}$ and monomethoxy polyethylene glycol (mPEG) (P4HB-mPEG) encapsulating the anticancer drug cisplatin. PEG is extensively used as hydrophilic non-toxic segment approved by the FDA for human use. NPs with mPEG incorporated on their surface have shown resistance against opsonization and phagocytosis, besides its prolonged residence time in blood. The surface modification also avoids the recognition of the NPs by macrophages, thus enables the sustained release of the encapsulated drug. Amphiphilic block copolymers possess the physicochemical characteristics of self-assembly and stability in aqueous solution. Hydrophobic drug molecules solubilize within the hydrophobic core while the shell protects the integrity of the micelle. For the fabrication of nanoparticles, low molecular weight block copolymers $\left(M_{w} 5 \times 10^{3}-9 \times 10^{3} \mathrm{~g} \mathrm{~mol}^{-1}\right)$ were used (Shah et al., 2010). Cells of mouse hippocampal HT22 were treated with the fabricated NPs with and without encapsulated cisplatin, an anticancer agent. Suppression effect on the cell growth of HT22 was observed by flow cytometry and confocal microscopy when cells were treated with cisplatin loaded nanocarriers. Moreover, cell apoptosis observed using NPs with cisplatin encapsulated was comparable with the situation when the free drug was used to treat the cells. Similarly, copolymers of $4 \mathrm{HB}$ with $3 \mathrm{HB}$ or $3 \mathrm{HV}$ were also used for preparing nanocarriers (Shah et al., 2010, 2012). Tepha Inc. patented in 2005 (publication number: United States 20050025809A1) controlled release systems using nanospheres, microparticles, and microcapsules of $\mathrm{P} 4 \mathrm{HB}$ and copolymers for sustained drug delivery. On Tepha's website, matrices for drug delivery from $\mathrm{P} 4 \mathrm{HB}$ is described as under development. Absorbable microspheres for tissue bulking procedures, endovascular embolization, and cosmetic surgery are also reported as potential bioproducts of $\mathrm{P} 4 \mathrm{HB}$ (see text footnote 2). Recently, Zhang et al. (2018) and RodriguezContreras (2019) published comprehensive reviews on medical applications of PHAs.

\section{FUTURE CHALLENGES OF P4HB IN THE MARKET}

Among other, two aspects are highlighted to tackle the expansion of $\mathrm{P} 4 \mathrm{HB}$ commercial applications. One is lowering the production costs of $\mathrm{P} 4 \mathrm{HB}$ and the second is to identify high value added applications for $\mathrm{P} 4 \mathrm{HB}$ in complement to the medical use of this material. Similar to the rapid development of PLA promoted by NatureWorks LLC (Minnesota, United States) as a bulk bioplastic, which is today one of the most representative bio-based plastics, better availability of $\mathrm{P} 4 \mathrm{HB}$ will speed up its development into new materials with unique properties. To lower $\mathrm{P} 4 \mathrm{HB}$ production costs, isolation and selection of robust $\mathrm{P} 4 \mathrm{HB}$ native producers and/or strain genetic engineering with a rational design for the efficient synthesis of $\mathrm{P} 4 \mathrm{HB}$ having as a basis the large scientific progress done in this direction as reviewed in this paper. A major challenge is the high and stable synthesis of $\mathrm{P} 4 \mathrm{HB}$ from inexpensive/structurally unrelated carbon sources, which is only achievable in recombinant strains. In addition, bioprocess engineering to implement an optimized process on inexpensive medium and substrates is essential to increase the productivity and reduce the costs. Finally, environmentally friendly, simple, efficient, inexpensive, and scalable methods for extraction of $\mathrm{P} 4 \mathrm{HB}$ from cells resulting in polymers with a range of purity, including the ones considered endotoxin-free, are yet to be reported and would largely contribute to improve the overall 
process of P4HB production (Resch et al., 1998; Gao et al., 2013). Synthesis of $\mathrm{P} 4 \mathrm{HB}$ with tailored molecular weights according to requirements for different applications would expand even more the uses of this material. $\mathrm{P} 4 \mathrm{HB}$ with ultra-high molecular weights of over several millions has been biosynthesized (Boesel et al., 2014). To date, it is not clear yet what determines the molecular weight and distribution of PHA produced in native and recombinant bacteria. The concentration and catalytical activity of PhaC, the occurrence of chain transfer reactions, and if PHA biosynthesis takes place or not in parallel to degradation, are known to play a role in determining the PHA molecular weight (Tsuge, 2016). Ultra-high molecular weight PHA can be turned into high strength fibers. On the other hand, low molecular weight $\mathrm{P} 4 \mathrm{HB}$ could be employed for example for drug delivery and as plasticizer. However, these and many other properties are underexplored because of the limited availability of this material due to patent protection and high cost in comparison to the biopolymers produced globally. An increase in production volume would trigger a cheaper correct to price and contribute to a significant increase of variety also with cost-effective applications of P4HB: A classical chicken and egg situation. In order to establish both, a sustainable demand and supply of $\mathrm{P} 4 \mathrm{HB}$, the increase of the relevancy of $\mathrm{P} 4 \mathrm{HB}$, meaning an increase of the visibility along with a gain of knowledge triggered by more intensified research. Along with the scaleup of production, a suitable distribution network with customer service explaining the particular processing of $\mathrm{P} 4 \mathrm{HB}$ has to be implemented. In counterpoint, even though $\mathrm{P} 4 \mathrm{HB}$ has the FDA approval for medical applications, the increase of $\mathrm{P} 4 \mathrm{HB}$ accessibility could give rise to its abusive uses.

\section{CONCLUSION}

More than 30 years after the discovery of a copolymer containing $4 \mathrm{HB}$ and despite the wide range of potential

\section{REFERENCES}

Ahn, W. S., Park, S. J., and Lee, S. Y. (2000). Production of poly(3-hydroxybutyrate) by fed-batch culture of recombinant Escherichia coli with a highly concentrated whey solution. Appl. Environ. Microbiol. 66, 3624-3627. doi: 10.1128/aem.66.8. 3624-3627.2000

Albuquerque, P. B. S., and Malafaia, C. B. (2018). Perspectives on the production, structural characteristics and potential applications of bioplastics derived from polyhydroxyalkanoates. Int. J. Biol. Macromol. 107(Pt A), 615-625. doi: 10. 1016/j.ijbiomac.2017.09.026

Amstutz, V., Hanik, N., Pott, J., Utsunomia, C., and Zinn, M. (2019). "Chapter Four - Tailored biosynthesis of polyhydroxyalkanoares in chemostat cultures," in Methods in Enzymology, Vol. 627, ed. N. Bruns and K. Loos (Cambridge, MA: Academic Press), 99-123. doi: 10.1016/bs.mie.2019.08.018

Anderson, E., Licata, J., and Van Walsem, J. (2006). Single Solvent Polymer Extraction Methods. United States Patent Application 20100311940. International Application No WO2006031492A1.

Azira, T. M. F., Nursolehah, A. A., Norhayati, Y., Majid, M. I. A., and Amirul, A. A. (2011). Biosynthesis of Poly(3-hydroxybutyrate-co-3-hydroxyvalerate-co4-hydroxybutyrate) terpolymer by Cupriavidus sp. USMAA2-4 through twostep cultivation process. World J. Microbiol. Biotechnol. 27, 2287-2295. doi: 10.1007/s11274-011-0693-7 applications in industry, to date, the medical applications of P4HB are still the most economically practical area. P4HB has been studied mostly for bio-implant applications showing good biocompatibility, biodegradability, appropriate stability, and good mechanical properties especially with respect to strength and ductility. After 10 years of clinical trial $\mathrm{P} 4 \mathrm{HB}$ received its first FDA clearance in 2007. Currently, P4HB is the only PHA that can be commercially used for medical applications and the reasons for it includes the time and investment required for receiving the FDA medical approval. Reduction of production costs, expansion of P4HB utilization in more routine applications (like it is the case for PLA) which could come across approval constraints (due to the psychoactive effects of the degradation product $4 \mathrm{HB}$ ), and the development of new biomaterials for various smart medical and therapeutical applications, are on the future path of the auspicious biopolyester $\mathrm{P} 4 \mathrm{HB}$.

\section{AUTHOR CONTRIBUTIONS}

$\mathrm{CU}$ and $\mathrm{QR}$ wrote the manuscript. QR and MZ contributed with critical feedback and revisions. All authors contributed to the manuscript revision, read and approved the submitted version.

\section{FUNDING}

This work was supported by the program Innovation in Biocatalysis: A toolbox for sustainable bio-based production in the frame of the project based contributions (State Secretariat for Education, Research and Innovation SERI, Switzerland), and by the financial support of HES-SO Valais-Wallis for Research and Development.

Bailey, W. J., Ni, Z., and Wu, S. R. (1982). Synthesis of poly- $\epsilon$-caprolactone via a free radical mechanism. Free radical ring-opening polymerization of 2-methylene-1,3-dioxepane. J. Polym. Sci. Polym. Chem. Ed. 20, 3021-3030. doi: 10.1002/pol.1982.170201101

Behrend, D., Grabow, N., Martin, D. P., Schmitz, K., Sternberg, K., and Williams, S. F. (2007). Polymeric, Degradable Drug-Eluting Stents and Coatings. United States Patent Application 20100311940. International Publication No WO 2007/092418 A2.

Boesel, L. F., Le Meur, S., Thöny-Meyer, L., and Ren, Q. (2014). The effect of molecular weight on the material properties of biosynthesized poly(4hydroxybutyrate). Int. J. Biol. Macromol. 71, 124-130. doi: 10.1016/j.ijbiomac. 2014.04.015

Bostman, O. M. (1991). Absorbable implants for the fixation of fractures. J. Bone Joint Surg. A 73, 148-153. doi: 10.2106/00004623-199173010-00022

Brigham, C. J., and Sinskey, A. J. (2012). Applications of polyhydroxyalkanoates in the medical industry. Int. J. Biotechnol. Wellness Ind. 1, 52-60.

Bugnicourt, E., Cinelli, P., Lazzeri, A., and Alvarez, V. A. (2014). Polyhydroxyalkanoate (PHA): review of synthesis, characteristics, processing and potential applications in packaging. Express Pol. Lett. 8, 791-808. doi: 10.3144/expresspolymlett.2014.82

Burlakov, V. V., Letov, A. V., Arndt, P., Baumann, W., Spannenberg, A., Fischer, C., et al. (2003). Zwitterionic titanoxanes $\left\{\mathrm{Cp}\left[\eta^{5}-\mathrm{C}_{5} \mathrm{H}_{4} \mathrm{~B}\left(\mathrm{C}_{6} \mathrm{~F}_{5}\right)_{3}\right] \mathrm{Ti}\right\}_{2} \mathrm{O}$ and 
$\left\{\left(\eta^{5}-\mathrm{iPrC}_{5} \mathrm{H}_{4}\right)\left[\eta^{5}-1,3-\mathrm{iPrC}_{5} \mathrm{H}_{3} \mathrm{~B}\left(\mathrm{C}_{6} \mathrm{~F}_{5}\right)_{3}\right] \mathrm{Ti}\right\}_{2} \mathrm{O}$ as catalysts for cationic ringopening polymerization. J. Mol. Catal. A: Chem 200, 63-67. doi: 10.1016/s13811169(03)00023-2

Carter, L. P., Pardi, D., Gorsline, J., and Griffiths, R. R. (2009). Illicit gammahydroxybutyrate $(\mathrm{GHB})$ and pharmaceutical sodium oxybate $\left(\mathrm{Xyrem}^{\circledR}\right)$ : differences in characteristics and misuse. Drug Alcohol. Depend. 104, 1-10. doi: 10.1016/j.drugalcdep.2009.04.012

Cavalheiro, J. M. B. T., Raposo, R. S., de Almeida, M. C. M. D., Cesário, M. T., Sevrin, C., Grandfils, C., et al. (2012). Effect of cultivation parameters on the production of poly(3-hydroxybutyrate-co-4-hydroxybutyrate) and poly(3-hydroxybutyrate-4-hydroxybutyrate-3-hydroxyvalerate) by Cupriavidus necator using waste glycerol. Bioresour. Technol. 111, 391-397. doi: 10.1016/j.biortech.2012.01.176

Cesário, M. T., Raposo, R. S., de Almeida, M. C. M. D., Van Keulen, F., Ferreira, B. S., Telo, J. P., et al. (2014). Production of poly(3-hydroxybutyrate-co-4hydroxybutyrate) by Burkholderia sacchari using wheat straw hydrolysates and gamma-butyrolactone. Int. J. Biol. Macromol. 71, 59-67. doi: 10.1016/j. ijbiomac.2014.04.054

Chen, X., Yin, J., Ye, J., Zhang, H., Che, X., Ma, Y., et al. (2017). Engineering Halomonas bluephagenesis TD01 for non-sterile production of poly(3hydroxybutyrate-co-4-hydroxybutyrate). Bioresour. Technol. 244, 534-541. doi: 10.1016/j.biortech.2017.07.149

Cho, S., Shin, J., and Cho, B.-K. (2018). Applications of CRISPR/Cas system to bacterial metabolic engineering. Int. J. Mol. Sci. 19, 1089. doi: 10.3390/ ijms 19041089

Choi, M. H., Song, J. J., and Yoon, S. C. (1995). Biosynthesis of copolyesters by Hydrogenophaga pseudoflava from various lactones. Can. J. Microbiol. 41, 60-67. doi: 10.1139/m95-169

Choi, M. H., Yoon, S. C., and Lenz, R. W. (1999). Production of poly(3hydroxybutyric acid-co-4-hydroxybutyric acid) and poly(4-hydroxybutyric acid) without subsequent degradation by Hydrogenophaga pseudoflava. Appl. Environ. Microbiol. 65, 1570-1577. doi: 10.1128/aem.65.4.1570-1577.1999

Daley, S. M. E., Kappell, A. D., Carrick, M. J., and Burnap, R. L. (2012). Regulation of the cyanobacterial CO2-concentrating mechanism involves internal sensing of $\mathrm{NADP}^{+}$and $\alpha$-ketogutarate levels by transcription factor CcmR. PLoS ONE 7:e41286. doi: 10.1371/journal.pone.0041286

Deeken, C. R., and Matthews, B. D. (2013). Characterization of the mechanical strength, resorption properties, and histologic characteristics of a fully absorbable material (Poly-4-hydroxybutyrate-PHASIX Mesh) in a porcine model of hernia repair. Int. Schol. Res. Notices 2013:12

Dennis, D. E., and Valentin, H. E. (2000). Methods of Making Polyhydroxyalkanoates Comprising 4-Hydroxybutyrate Monomer Units. U.S. Patent No 6117658.

Doi, Y., Kawaguchi, Y., Koyama, N., Nakamura, S., Hiramitsu, M., Yoshida, Y., et al. (1992). Synthesis and degradation of polyhydroxyalkanoates in Alcaligenes eutrophus. FEMS Microbiol. Rev. 9, 103-108. doi: 10.1111/j.1574-6968.1992. tb05827.x

Doi, Y., Kunioka, M., Nakamura, Y., and Soga, K. (1988). Nuclear magnetic resonance studies on unusual bacterial copolyesters of 3-hydroxybutyrate and 4-hydroxybutyrate. Macromolecules 21, 2722-2727. doi: 10.1021/ma00187 a012

Doi, Y., Segawa, A., and Kunioka, M. (1990). Biosynthesis and characterization of poly(3-hydroxybutyrate-co-4-hydroxybutyrate) in Alcaligenes eutrophus. Int. J. Biol. Macromol. 12, 106-111. doi: 10.1016/0141-8130(90)90061-e

Drasbek, K. R., Christensen, J., and Jensen, K. (2006). Gamma-hydroxybutyrate-a drug of abuse. Acta Neurol. Scand. 114, 145-156. doi: 10.1111/j.1600-0404.2006. 00712.x

Duncan, R. (2006). Polymer conjugates as anticancer nanomedicines. Nat. Rev. Cancer 6, 688. doi: 10.1038/nrc1958

Engelberg, I., and Kohn, J. (1991). Physico-mechanical properties of degradable polymers used in medical applications: a comparative study. Biomaterials 12, 292-304. doi: 10.1016/0142-9612(91)90037-b

F.D.A. (1997). Guidance for Industry. Rockville: U.S. Department of Health and Human Services.

Felix, F., Fosco, A., Martin, D. P., Van Natta, B., Rizk, S., et al. (2015). Absorbable Implants for Plastic Surgery. United States Patent Application US20160022416A1. International Publication No WO 2015/006737 A1.
Furrer, P., Panke, S., and Zinn, M. (2007). Efficient recovery of low endotoxin medium-chain-length poly([R]-3-hydroxyalkanoate) from bacterial biomass. J. Microbiol. Methods 69, 206-213. doi: 10.1016/j.mimet.2007.01.002

Gao, Y., Feng, X., Xian, M., Wang, Q., and Zhao, G. (2013). Inducible cell lysis systems in microbial production of bio-based chemicals. Appl. Microbiol. Biotechnol. 97, 7121-7129. doi: 10.1007/s00253-013-5100-x

Greene J. P. (2014). "Biobased and biodegradable polymers," in Sustainable Plastics Environmental Assessements of Biobased, Biodegradable, and Recycled Plastics, ed. J. P. Greene (Hoboken, NJ: John Wiley \& Sons), 71-106. Available online at: https://www.wiley.com/en-do/Sustainable+Plastics\%3A+Environmental+ Assessments+of+Biobased $\% 2 \mathrm{C}+$ Biodegradable $\% 2 \mathrm{C}+$ and+Recycled+Plasticsp-9781118104811

Gross, R. A., Shi, F., and Ashby, R. D. (1997). Methods of Controlling Microbial Polyester Structure. International Publication No WO1997007153.

Hanik, N., Utsunomia, C., Arai, S., Matsumoto, K., and Zinn, M. (2019). Influence of unusual co-substrates on the biosynthesis of medium-chainlength polyhydroxyalkanoates produced in multistage chemostat. Front. Bioeng. Biotechnol. 7:301. doi: 10.3389/fbioe.2019.00301

Hein, S., Söhling, B., Gottschalk, G., and Steinbüchel, A. (1997). Biosynthesis of poly(4-hydroxybutyric acid) by recombinant strains of Escherichia coli. FEMS Microbiol. Lett. 153, 411-418. doi: 10.1016/s0378-1097(97)00282-6

Hein, S., Söhling, B., Gottschalk, G., and Steinbüchel, A. (1998). Methods for the Biosynthesis of Polyesters. United States Patent Application US7968325B2. International Publication No WO1998039453.

Hench, L. L., and Polak, J. M. (2002). Third-generation biomedical materials. Science 295, 1014-1017. doi: 10.1126/science.1067404

Hiroe, A., Tsuge, K., Nomura, C. T., Itaya, M., and Tsuge, T. (2012). Rearrangement of gene order in the phaCAB operon leads to effective production of ultrahigh-molecular-weight poly[(R)-3-hydroxybutyrate] in genetically engineered Escherichia coli. Appl. Environ. Microbiol. 78, 3177-3184. doi: 10.1128/aem.07715-11

Hong, M., and Chen, E. Y. (2016). Completely recyclable biopolymers with linear and cyclic topologies via ring-opening polymerization of $\gamma$-butyrolactone. Nat. Chem. 8, 42-49. doi: 10.1038/nchem.2391

Hori, Y., Yamaguchi, A., and Hagiwara, T. (1995). Chemical synthesis of high molecular weight poly(3-hydroxybutyrate-co-4-hydroxybutyrate). Polymer 36, 4703-4705. doi: 10.1016/0032-3861(95)96838-y

Horowitz, D. M., and Brennan, E. M. (2001). Methods for Separation and Purification of Biopolymers. U.S. Publication No 2001/0006802 A1.

Hosseini, V., Evrova, O., Hoerstrup, S. P., and Vogel, V. (2018). A simple modification method to obtain anisotropic and porous 3D microfibrillar scaffolds for surgical and biomedical applications. Small 14:1702650. doi: 10. 1002/smll.201702650

Hu, D., Chung, A.-L., Wu, L.-P., Zhang, X., Wu, Q., Chen, J.-C., et al. (2011). Biosynthesis and characterization of polyhydroxyalkanoate block copolymer P3HB-b-P4HB. Biomacromolecules 12, 3166-3173. doi: 10.1021/bm200 $660 \mathrm{k}$

Hubbs, J. C., and Harrison, M. N. (1996). Composition and Process for the Production of Poly(3-Hydroxyalkanoates). U.S. Patent No. 5,563,239.

Huisman, G. W., Skraly, F., Martin, D. P., and Peoples, O. P. (2002). Biological Systems for Manufacture of Polyhydroxyalkanoate Polymers Containing 4Hydroxyacids. U.S. Patent No US6689589.

Inoue, S., Tomoi, Y., Tsuruta, T., and Furukawa, J. (1961). Organometalliccatalyzed polymerization of propiolactone. Die Makromolekulare Chem. Macromol. Chem. Phys. 48, 229-233.

Jacquel, N., Lo, C.-W., Wei, Y.-H., Wu, H.-S., and Wang, S. S. (2008). Isolation and purification of bacterial poly(3-hydroxyalkanoates). Biochem. Eng. J. 39, 15-27. doi: 10.1016/j.bej.2007.11.029

Jendrossek, D. (2001). Microbial degradation of polyesters. Biopolyesters 71, 293325. doi: 10.1007/3-540-40021-4_10

Jendrossek, D. (2009). Polyhydroxyalkanoate granules are complex subcellular organelles (carbonosomes). J. Bacteriol. 191, 3195-3202. doi: 10.1128/jb.0172 3-08

Kampf, M. M., Thöny-Meyer, L., and Ren, Q. (2014). Biosynthesis of poly(4hydroxybutyrate) in recombinant Escherichia coli grown on glycerol is stimulated by propionic acid. Int J. Biol. Macromol. 71, 8-13. doi: 10.1016/j. ijbiomac.2014.04.023 
Kang, C.-K., Kusaka, S., and Doi, Y. (1995). Structure and properties of poly(3-hydroxybutyrate-co-4-hydroxybutyrate) produced by Alcaligenes latus. Biotechnol. Lett. 17, 583-588. doi: 10.1007/bf00129382

Katz, L., Chen, Y. Y., Gonzalez, R., Peterson, T. C., Zhao, H., and Baltz, R. H. (2018), Synthetic biology advances and applications in the biotechnology industry: a perspective. J. Ind. Microbiol. Biotechnol. 45, 449-461. doi: 10.1007/s10295-0182056-y

Kim, H. W., Chung, M. G., and Rhee, Y. H. (2007). Biosynthesis, modification, and biodegradation of bacterial medium-chain-length polyhydroxyalkanoates. J. Microbiol. 45, 87-97.

Kim, J. S., Lee, B. H., and Kim, B. S. (2005). Production of poly(3-hydroxybutyrateco-4-hydroxybutyrate) by Ralstonia eutropha. Biochem. Eng. J. 23, 169-174. doi: 10.1016/j.bej.2005.01.016

Koller, M., Atliæ, A., Dias, M., Reiterer, A., and Braunegg, G. (2010). "Microbial PHA production from waste raw materials," in Plastics from bacteria, ed. G. Q. Chen (Berlin: Springer), 85-119. doi: 10.1007/978-3-642-03287-5_5

Koller, M., Marsalek, L., de Sousa Dias, M. M., and Braunegg, G. (2017). Producing microbial polyhydroxyalkanoate (PHA) biopolyesters in a sustainable manner. N. Biotechnol. 37(Pt A), 24-38. doi: 10.1016/j.nbt.2016.05.001

Kourmentza, C., Placido, J., Venetsaneas, N., Burniol-Figols, A., Varrone, C., Gavala, H. N., et al. (2017). Recent advances and challenges towards sustainable polyhydroxyalkanoate (PHA) production. Bioengineering (Basel) 4:E55. doi: 10.3390/bioengineering4020055

Koyama, N., and Doi, Y. (1995). Morphology and biodegradability of a binary blend of poly $((R)$-3-hydroxybutyric acid $)$ and poly $((R, S)$-lactic acid). Can. J. Microbiol. 41, 316-322. doi: 10.1139/m95-203

Krishnaswamy, R. K. (2012). Biodegradable coextruded multilayer films. International Publication No WO 201, A1.

Książek, A. A., Mitchell, K. J., Cesarovic, N., Schwarzwald, C. C., Hoerstrup, S. P., and Weber, B. (2016). PGA (polyglycolic acid)-P4HB (poly-4hydroxybutyrate)-based bioengineered valves in the rat aortic circulation. J. Heart Valve Dis. 25, 380-388.

Kunioka, M., and Doi, Y. (1990). Thermal degradation of microbial copolyesters: poly(3-hydroxybutyrate-co-3-hydroxyvalerate) and poly(3hydroxybutyrate-co-4-hydroxybutyrate). Macromolecules 23, 1933-1936. doi: $10.1021 / \mathrm{ma} 00209 \mathrm{a} 009$

Kunioka, M., Nakamura, Y., and Doi, Y. (1988). New bacterial copolyesters produced in Alcaligenes eutrophus from organic acids. Polym. Commun. 29, 174-176.

Kurdikar, D. L., Strauser, F. E., Solodar, A. J., and Paster, M. D. (2000). High Temperature PHA Extraction Using PHA-Poor Solvents. U.S. Patent No. $6,087,471$.

Kurdikar, D. L., Strauser, F. E., Solodar, A. J., Paster, M. D., and Asrar, J. (1998). Methods of PHA Extraction and Recovery Using non-Halogenated Solvents. United States Patent Application US6043063A. International Publication No WO1998046782A1.

Lafferty, R. M., and Heinzle, E. (1978). Cyclic Carbonic Acid Esters as Solvents for

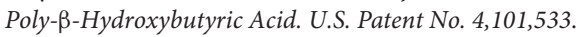

Le, J. K., and Richards, J. R. (2019). "Gamma-hydroxybutyrate (GHB, "G", Liquid $\mathrm{X}$, Liquid E, Juice, Mils, Fantasy) Toxicity," in StatPearls [Internet] (Treasure Island, FL: StatPearls Publishing). Available online from: https://www.ncbi.nlm. nih.gov/books/NBK430781/

Le Meur, S., Zinn, M., Egli, T., Thöny-Meyer, L., and Ren, Q. (2013). Poly(4hydroxybutyrate) (P4HB) production in recombinant Escherichia coli: $\mathrm{P} 4 \mathrm{HB}$ synthesis is uncoupled with cell growth. Microb. Cell Fact. 12, 123. doi: 10.1186/ 1475-2859-12-123

Le Meur, S., Zinn, M., Egli, T., Thöny-Meyer, L., and Ren, Q. (2014). Improved productivity of poly(4-hydroxybutyrate) (P4HB) in recombinant Escherichia coli using glycerol as the growth substrate with fed-batch culture. Microb. Cell Fact. 13, 131.

Lee, S. Y., Choi, J.-I., Han, K., and Song, J. Y. (1999). Removal of endotoxin during purification of poly(3-hydroxybutyrate) from gram-negative bacteria. Appl. Environ. Microbiol. 65, 2762-2764. doi: 10.1128/aem.65.6.2762-2764. 1999

Lee, W.-H., Azizan, M. N. M., and Sudesh, K. (2004). Effects of culture conditions on the composition of poly(3-hydroxybutyrate-co-4-hydroxybutyrate) synthesized by Comamonas acidovorans. Polym. Degrad. Stab. 84, 129-134. doi: 10.1016/j.polymdegradstab.2003.10.003
Lee, Y.-H., Kang, M.-S., and Jung, Y.-M. (2000). Regulating the molar fraction of 4-hydroxybutyrate in poly(3-hydroxybutyrate-4-hydroxybutyrate) biosynthesis by Ralstonia eutropha using propionate as a stimulator. J.Biosci. Bioeng. 89, 380-383. doi: 10.1016/s1389-1723(00)88963-x

Lemoigne, M. (1926). Produits de deshydration et de polymerisation de L'acide $\beta=$ Oxybutyrique. Bull. Soc. Chim. Biol. 8, 770-782.

Lenz, R. W., and Marchessault, R. H. (2005). Bacterial polyesters: biosynthesis, biodegradable plastics and biotechnology. Biomacromolecules 6, 1-8. doi: 10. $1021 / \mathrm{bm} 049700 \mathrm{c}$

Li, T., Ye, J., Yin, J., and Chen, X. (2018). Gene cassette for fine control of composition ratio of 4-hydroxybutanoic acid in copolymer and application thereof. International Publication No WO2018233703.

Li, Z.-J., Shi, Z.-Y., Jian, J., Guo, Y.-Y., Wu, Q., and Chen, G.-Q. (2010). Production of poly(3-hydroxybutyrate-co-4-hydroxybutyrate) from unrelated carbon sources by metabolically engineered Escherichia coli. Metab. Eng. 12, 352-359. doi: 10.1016/j.ymben.2010.03.003

Liddell, J. M. (1999). Process for the Recovery of Polyhydroxyalkanoic Acid. U.S. Patent No. 5,894,062.

Lide, D. R. (2005). Handbook of Chemistry and Physics, 86th Edn. Boca Raton, FL: CRC Taylor \& Francis.

Lu, J., Tappel, R. C., and Nomura, C. T. (2009). Mini-review: biosynthesis of poly(hydroxyalkanoates). J. Macromol. Sci. Polymer Rev. 49, 226-248. doi: 10. 1080/15583720903048243

Lv, L., Ren, Y.-L., Chen, J.-C., Wu, Q., and Chen, G.-Q. (2015). Application of CRISPRi for prokaryotic metabolic engineering involving multiple genes, a case study: controllable P(3HB-co-4HB) biosynthesis. Metab. Eng. 29, 160-168. doi: 10.1016/j.ymben.2015.03.013

Mantelatto, P. E., Duzzi, A. M., Sato, T., Durão, N. A. S., Nonato, R. V., Rocchiccioli, C., et al. (2005). Process for recovering polyhydroxialkanoates ("PHAS") from cellular biomass. United States Patent Application US8357508B2. International Publication No WO2005052175A2.

Martin, D. P., Crabtree, D., and Williams, S. F. (2006). Embolization using poly-4hydroxybutyrate particles. United States Patent Application US20060177513A1. International Publication No WO 2006/081517 A2.

Martin, D. P., Rizk, S., Ahuja, A., and Williams, S. F. (2004). Polyhydroxyalkanoate Medical Textiles and Fibers. United States Patent Application US9125719B2. International Publication No WO 2004/101002 A2.

Martin, D. P., and Williams, S. F. (2003). Medical applications of poly-4hydroxybutyrate: a strong flexible absorbable biomaterial. Biochem. Eng. J. 16, 97-105. doi: 10.1016/s1369-703x(03)00040-8

Mendonça, T. T., Gomez, J. G. C., Buffoni, E., Sánchez Rodriguez, R. J., Schripsema, J., Lopes, M. S. G., et al. (2014). Exploring the potential of Burkholderia sacchari to produce polyhydroxyalkanoates. J. Appl. Microbiol. 116, 815-829. doi: 10. 1111/jam. 12406

Mitomo, H., Hsieh, W. C., Nishiwaki, K., Kasuya, K., and Doi, Y. (2001). Poly(3hydroxybutyrate-co-4-hydroxybutyrate) produced by Comamonas acidovorans. Polymer 42, 3455-3461. doi: 10.1016/s0032-3861(00)00678-9

Miura, H., Tajima, T., Nagata, M., Royama, T., Saito, K., and Hasegawa, M. (1999). Synthesis of poly(ester ether)s by the reaction of $\gamma$-butyrolactone with diols and their application to polyurethanes. Kobunshi Ronbunshu 56, 291-297. doi: 10.1295/koron.56.291

Moore, T., Adhikari, R., and Gunatillake, P. (2005). Chemosynthesis of bioresorbable poly( $\gamma$-butyrolactone) by ring-opening polymerisation: a review. Biomaterials 26, 3771-3782. doi: 10.1016/j.biomaterials.2004.10.002

Narasimhan, K., Cearley, A., Gibson, M., and Welling, S. (2005). Process for the Solvent-Based Extraction of Polyhydroxyalkanoates from Biomass. U.S. Patent No 2005/0287654 A1.

Nelson, T., Kaufman, E., Kline, J., and Sokoloff, L. (1981). The extraneural distribution of $\gamma$-hydroxybutyrate. J. Neurochem. 37, 1345-1341.

Niaounakis, M. (2015). "Chapter 1 - Introduction," in Biopolymers: Processing and Products, ed. M. Niaounakis (Norwich, NY: William Andrew Publishing), 1-77. doi: 10.1016/B978-0-323-26698-7.00001-5

Nobes, G. A. R., Kazlauskas, R. J., and Marchessault, R. H. (1996). Lipase-catalyzed ring-opening polymerization of lactones: a novel route to poly(hydroxyalkanoate)s. Macromolecules 29, 4829-4833. doi: $10.1021 / \mathrm{ma} 951774 \mathrm{~g}$

Noda, I. (1998a). Process for Recovering Polyhydroxyalkanotes Using Air Classification. U.S. Patent No. 5,849,854. 
Noda, I. (1998b). Solvent Extraction of Polyhydroxy-Alkanoates from Biomass Facilitated by the Use of Marginal Nonsolvent. U.S. Patent No. 5,821,299.

Noda, I., and Schechtman, L. A. (1997). Solvent Extraction of PolyhydroxyAlkanoates from Biomass. United States Patent Application WO2014125422A9. International Publication No WO1997007230A1.

Noel, B. J. (1962). Process for Preparing Poly- $\beta$-Hydroxybutyric Acid. U.S. Patent No. $3,044,942$.

Oishi, A., Taguchi, Y., Fujita, K., Ikeda, Y., and Masuda, T. (2000). Production of Poly- $\gamma$-Butyrolactone. Japanese Patent No JP2000281767.

O’Neil, M. J. (2013). The Merck index: An Encyclopedia of Chemicals, Drugs, and Biologicals. Cambridge: RSC Publishing.

Ong, S. Y., Chee, J. Y., and Sudesh, K. (2017). Degradation of polyhydroxyalkanoate (PHA): a review. J. Sib. Fed. Univ. Biol. 10, 211.

Petsch, D., and Anspach, F. B. (2000). Endotoxin removal from protein solutions. J. Biotechnol. 76, 97-119. doi: 10.1016/s0168-1656(99)00185-6

PlasticsEurope, (2019). Plastics - The Facts 2019: An Analysis of European Plastics Production, Demand and Waste Data. Brussels: PlasticsEurope

Pötter, M., Müller, H., and Steinbüchel, A. (2005). Influence of homologous phasins (PhaP) on PHA accumulation and regulation of their expression by the transcriptional repressor PhaR in Ralstonia eutropha H16. Microbiology 151, 825-833. doi: 10.1099/mic.0.27613-0

Pries, A., Priefert, H., Krüger, N., and Steinbüchel, A. (1991). Identification and characterization of two Alcaligenes eutrophus gene loci relevant to the poly(betahydroxybutyric acid)-leaky phenotype which exhibit homology to $p t s H$ and $p t s I$ of Escherichia coli. J. Bacteriol. 173, 5843-5853. doi: 10.1128/jb.173.18.58435853.1991

Ramseier, T. M., Bickmeier, J. A., Farmer, W. R., Morse, C., Chinnapen, H., Peoples, O. P., et al. (2014). Polyhydroxyalkanoate Copolymer Compositions and Methods of Making the Same. United States Patent Application WO2014058655A8. International Publication No WO2014058655.

Resch, S., Gruber, K., Wanner, G., Slater, S., Dennis, D., and Lubitz, W. (1998). Aqueous release and purification of poly( $\beta$-hydroxybutyrate) from Escherichia coli. J. Biotechnol. 65, 173-182. doi: 10.1016/s0168-1656(98)00127-8

Rizk, S., Martin, D. P., Ho, K., and Williams, S. F. (2008). Medical Devices Containing Oriented Films of Poly-4-Hydroxybutyrate and Copolymers. United States Patent Application US20080132602A1. International Application No WO 2008/070428 A2.

Rodriguez-Contreras, A. (2019). Recent advances in the use of polyhydroyalkanoates in biomedicine. Bioengineering 6:82. doi: 10.3390/ bioengineering6030082

Saito, Y., Nakamura, S., Hiramitsu, M., and Doi, Y. (1996). Microbial synthesis and properties of poly(3-hydroxybutyrate-co-4-hydroxybutyrate). Polym. Int. 39, 169-174. doi: 10.1002/(sici)1097-0126(199603)39:3<169::aid-pi453>3.0. co; $2-\mathrm{z}$

Sendelbeck, S. L., and Girdis, C. L. (1985). Disposition of a 14C-labeled bioerodible polyorthoester and its hydrolysis products, 4-hydroxybutyrate and cis, trans1,4-bis(hydroxymethyl) cyclohexane, in rats. Drug Metab. Dispos. 13, 291-295.

Serjeant, E. P., and Dempsey, B. (1979). Ionisation Constants of Organic acids in Aqueous Solution. New York, NY: Pergamon Press.

Shah, M., Naseer, M. I., Choi, M. H., Kim, M. O., and Yoon, S. C. (2010). Amphiphilic PHA-mPEG copolymeric nanocontainers for drug delivery: preparation, characterization and in vitro evaluation. Int. J. Pharm. 400, 165175. doi: 10.1016/j.ijpharm.2010.08.008

Shah, M., Ullah, N., Choi, M. H., Kim, M. O., and Yoon, S. C. (2012). Amorphous amphiphilic $\mathrm{P}(3 \mathrm{HV}-c o-4 \mathrm{HB})-b$-mPEG block copolymer synthesized from bacterial copolyester via melt transesterification: nanoparticle preparation, cisplatin-loading for cancer therapy and in vitro evaluation. Eur. J. Pharm. Biopharm. 80, 518-527. doi: 10.1016/j.ejpb.2011.11.014

Shah, M., Ullah, N., Choi, M. H., and Yoon, S. C. (2014). Nanoscale poly(4hydroxybutyrate)-mPEG carriers for anticancer drugs delivery. J. Nanosci. Nanotechnol. 14, 8416-8421. doi: 10.1166/jnn.2014.9924

Sodian, R., Sperling, J. S., Martin, D. P., Egozy, A., Stock, U., Mayer, J. E. Jr., et al. (2000). Technical report: fabrication of a trileaflet heart valve scaffold from a polyhydroxyalkanoate biopolyester for use in tissue engineering. Tissue Eng. 6, 183-188. doi: $10.1089 / 107632700320793$

Söhling, B., and Gottschalk, G. (1996). Molecular analysis of the anaerobic succinate degradation pathway in Clostridium kluyveri. J. Bacteriol. 178, 871880. doi: 10.1128/jb.178.3.871-880.1996
Som, C., Schmutz, M., Borges, O., Jesus, S., Borchard, G., Nguyen, V., et al. (2019). Guidelines for Implementing a Safe-by-Design approach for Medicinal Polymeric Nanocarriers. St. Gallen: Empa.

Steinbüchel, A., and Lütke-Eversloh, T. (2003). Metabolic engineering and pathway construction for biotechnological production of relevant polyhydroxyalkanoates in microorganisms. Biochem. Eng. J. 16, 81-96. doi: $10.1016 / \mathrm{s} 1369-703 x(03) 00036-6$

Steinbüchel, A., Valentin, H. E., and Schönebaum, A. (1994). Application of recombinant gene technology for production of polyhydroxyalkanoic acids: biosynthesis of poly(4-hydroxybutyric acid) homopolyester. J. Environ. Polym. Degrad. 2, 67-74. doi: 10.1007/bf02074775

Stock, U. A., Sakamoto, T., Hatsuoka, S., Martin, D. P., Nagashima, M., Moran, A. M., et al. (2000). Patch augmentation of the pulmonary artery with bioabsorbable polymers and autologous cell seeding. J. Thorac. Cardiovasc. Surg. 120, 1158-1167. doi: 10.1067/mtc.2000.109539

Sudesh, K., Abe, H., and Doi, Y. (2000). Synthesis, structure and properties of polyhydroxyalkanoates: biological polyesters. Prog. Polym. Sci. 25, 1503-1555. doi: 10.1016/s0079-6700(00)00035-6

Sudesh, K., Fukui, T., and Doi, Y. (1998). Genetic analysis of Comamonas acidovorans polyhydroxyalkanoate synthase and factors affecting the incorporation of 4-hydroxybutyrate monomer. Appl. Environ. Microbiol. 64, 3437-3443. doi: 10.1128/aem.64.9.3437-3443.1998

Sudesh, K., Fukui, T., Taguchi, K., Iwata, T., and Doi, Y. (1999). Improved production of poly(4-hydroxybutyrate) by Comamonas acidovorans and its freeze-fracture morphology. Int. J. Biol. Macromol. 25, 79-85. doi: 10.1016/ s0141-8130(99)00018-5

Tsai, Y.-P., Lu, M.-S., Yang, C.-C., Shiu, H., and Lin, J.-W. (2019). Method for Extracting Polyhydroxyalkanoates (PHAs)). U.S. Patent No 2019/0127727 A1.

Tsuge, T. (2016). Fundamental factors determining the molecular weight of polyhydroxyalkanoate during biosynthesis. Polym. J. 48, 1051. doi: 10.1038/pj. 2016.78

Tyler, B., Gullotti, D., Mangraviti, A., Utsuki, T., and Brem, H. (2016). Polylactic acid (PLA) controlled delivery carriers for biomedical applications. Adv. Drug Delivery Rev. 107, 163-175. doi: 10.1016/j.addr.2016. 06.018

Valappil, S. P., Misra, S. K., Boccaccini, A. R., and Roy, I. (2006). Biomedical applications of polyhydroxyalkanoates, an overview of animal testing and in vivo responses. Expert Rev. Med. Devices 3, 853-868. doi: 10.1586/17434440. 3.6.853

Valentin, H. E., and Dennis, D. (1997). Production of poly(3-hydroxybutyrateco-4-hydroxybutyrate) in recombinant Escherichia coli grown on glucose. J. Biotechnol. 58, 33-38. doi: 10.1016/s0168-1656(97)00127-2

Valentin, H. E., Reiser, S., and Gruys, K. J. (2000). Poly(3-hydroxybutyrate-co-4hydroxybutyrate) formation from $\gamma$-aminobutyrate and glutamate. Biotechnol. Bioeng. 67, 291-299. doi: 10.1002/(sici)1097-0290(20000205)67:3<291::aidbit5>3.0.co;2-j

Valentin, H. E., Zwingmann, G., Schönebaum, A., and Steinbüchel, A. (1995). Metabolic pathway for biosynthesis of poly(3-hydroxybutyrate-co-4hydroxybutyrate) from 4-hydroxybutyrate by Alcaligenes eutrophus. Eur. J. Biochem. 227, 43-60. doi: 10.1111/j.1432-1033.1995.tb20358.x

van Noorden, M., Kamal, R., Dijkstra, B., Brunt, T. M., and de Jong, C. (2016). "Gamma-hydroxybutyrate abuse and dependence," in Neuropathology of Drug Addictions and Substance Misuse, ed. V. R. Preedy (Amsterdam: Elsevier), 379-387. doi: 10.1016/b978-0-12-800212-4.00036-4

Wampfler, B., Ramsauer, T., Kehl, K., Zinn, M., and Thöny-Meyer, L. (2010). Application of activated charcoal in the downstream processing of bacterial olefinic poly(3-hydroxyalkanoates). CHIMIA 64, 784-788. doi: 10.2533/chimia. 2010.784

Weber, B., Emmert, M. Y., Behr, L., Schoenauer, R., Drögemüller, C., et al. (2012). Prenatally engineered autologous amniotic fluid stem cell-based heart valves in the fetal circulation. Biomaterials 33, 4031-4043. doi: 10.1016/j.biomaterials. 2011.11.087

Williams, S. F. (2001). Flushable Disposable Polymeric Products. International Publication No WO 2001/015671 A2.

Williams, S. F., and Martin, D. P. (2001). Polyhydroxyalkanoate Compositions for Soft Tissue Repair, Augmentation, and Viscosupplementation. United States Patent Application US7025980B1. International Publication No WO 2001/019422 A1. 
Williams, S. F., Martin, D. P., Horowitz, D. M., and Peoples, O. P. (1999). PHA applications: addressing the price performance issue: I. Tissue engineering. Int. J. Biol. Macromol. 25, 111-121. doi: 10.1016/s0141-8130(99)000 22-7

Williams, S. F., Martin, D. P., and Moses, A. C. (2016). The history of GalaFLEX P4HB scaffold. Aesthetic Surg. J. 36(Suppl._2), S33-S42.

Williams, S. F., Rizk, S., and Martin, D. P. (2013). Poly-4-hydroxybutyrate $(\mathrm{P} 4 \mathrm{HB})$ : a new generation of resorbable medical devices for tissue repair and regeneration. Biomed. Technol. (Berl.) 58, 439-452.

Wu, Q., Wang, Y., and Chen, G.-Q. (2009). Medical application of microbial biopolyesters polyhydroxyalkanoates. Artif. Cells, Blood Substitutes, Biotechnol. 37, 1-12. doi: 10.1080/1073119080266 4429

Ye, J., Hu, D., Che, X., Jiang, X., Li, T., Chen, J., et al. (2018a). Engineering of Halomonas bluephagenesis for low cost production of poly(3-hydroxybutyrateco-4-hydroxybutyrate) from glucose. Metab. Eng. 47, 143-152. doi: 10.1016/j. ymben.2018.03.013

Ye, J., Huang, W., Wang, D., Chen, F., Yin, J., Li, T., et al. (2018b). Pilot scale-up of poly(3-hydroxybutyrate-co-4-hydroxybutyrate) production by Halomonas bluephagenesis via cell growth adapted optimization process. Biotechnol. J. 13, 1800074. doi: 10.1002/biot.201800074

Zhang, J., Shishatskaya, E. I., Volova, T. G., da Silva, L. F., and Chen, G. Q. (2018). Polyhydroxyalkanoates (PHA) for therapeutic applications. Mater. Sci. Eng. C Mater. Biol. Appl. 86, 144-150. doi: 10.1016/j.msec.2017. 12.035

Zhang, L., Shi, Z. Y., Wu, Q., and Chen, G. Q. (2009). Microbial production of 4hydroxybutyrate, poly-4-hydroxybutyrate, and poly(3-hydroxybutyrate-co-4hydroxybutyrate) by recombinant microorganisms. Appl. Microbiol. Biotechnol. 84, 909-916. doi: 10.1007/s00253-009-2023-7
Zhang, L.-J., Deng, X.-X., Du, F.-S., and Li, Z.-C. (2013). Chemical synthesis of functional poly(4-hydroxybutyrate) with controlled degradation via intramolecular cyclization. Macromolecules 46, 9554-9562. doi: 10.1021/ ma402191r

Zhang, S., Liu, Y., and Bryant, D. A. (2015). Metabolic engineering of Synechococcus sp. PCC 7002 to produce poly-3-hydroxybutyrate and poly-3-hydroxybutyrateco-4-hydroxybutyrate. Metab. Eng. 32, 174-183. doi: 10.1016/j.ymben.2015.1 0.001

Zhou, X.-Y., Yuan, X.-X., Shi, Z.-Y., Meng, D.-C., Jiang, W.-J., Wu, L.-P., et al. (2012). Hyperproduction of poly(4-hydroxybutyrate) from glucose by recombinant Escherichia coli. Microb. Cell Fact. 11, 54. doi: 10.1186/1475-285911-54

Zinn, M., and Hany, R. (2005). Tailored material properties of polyhydroxyalkanoates through biosynthesis and chemical modification. Adv. Eng. Mater. 7, 408-411. doi: 10.1002/adem.200500053

Zinn, M., Witholt, B., and Egli, T. (2001). Occurrence, synthesis and medical application of bacterial polyhydroxyalkanoate. Adv. Drug Delivery Rev. 53, 5-21. doi: 10.1016/s0169-409x(01)00218-6

Conflict of Interest: The authors declare that the research was conducted in the absence of any commercial or financial relationships that could be construed as a potential conflict of interest.

Copyright (C) 2020 Utsunomia, Ren and Zinn. This is an open-access article distributed under the terms of the Creative Commons Attribution License (CC BY). The use, distribution or reproduction in other forums is permitted, provided the original author(s) and the copyright owner(s) are credited and that the original publication in this journal is cited, in accordance with accepted academic practice. No use, distribution or reproduction is permitted which does not comply with these terms. 